\title{
Prognostic impact of concurrent MYC and BCL6 rearrangements and expression in de novo diffuse large B-cell lymphoma
}

\author{
Qing Ye ${ }^{1, *}$, Zijun Y. Xu-Monette ${ }^{1, *}$, Alexandar Tzankov ${ }^{2, *}$, Lijuan Deng ${ }^{1}$, Xiaoxiao \\ Wang ${ }^{1}$, Ganiraju C. Manyam ${ }^{3}$, Carlo Visco ${ }^{4}$, Santiago Montes-Moreno ${ }^{5}$, Li Zhang ${ }^{3}$, \\ Karen Dybkær ${ }^{6}$, April Chiu ${ }^{7}$, Attilio Orazi ${ }^{8}$, Youli Zu ${ }^{9}$, Govind Bhagat $^{10}$, Kristy L. \\ Richards ${ }^{11}$, Eric D. Hsi ${ }^{12}$, William W.L. Choi ${ }^{13}$, J. Han van Krieken ${ }^{14}$, Jooryung Huh ${ }^{15}$, \\ Maurilio Ponzoni ${ }^{16}$, Andrés J.M. Ferreri ${ }^{16}$, Ben M. Parsons ${ }^{17}$, Michael B. Møller ${ }^{18}$, \\ Miguel A. Piris ${ }^{5}$, Jane N. Winter ${ }^{19}$, L. Jeffrey Medeiros ${ }^{1}$ Shimin $\mathbf{H u}^{1}$ and Ken $\mathbf{H}$. \\ Young ${ }^{1,20}$ \\ ${ }^{1}$ Department of Hematopathology, The University of Texas MD Anderson Cancer Center, Houston, Texas, USA \\ 2 University Hospital, Basel, Switzerland \\ ${ }^{3}$ Department of Computational Biology and Bioinformatics, The University of Texas MD Anderson Cancer Center, Houston, \\ Texas, USA \\ ${ }^{4}$ San Bortolo Hospital, Vicenza, Italy \\ ${ }^{5}$ Hospital Universitario Marques de Valdecilla, Santander, Spain \\ ${ }^{6}$ Aalborg University Hospital, Aalborg, Denmark \\ ${ }^{7}$ Memorial Sloan-Kettering Cancer Center, New York, New York, USA \\ ${ }^{8}$ Weill Medical College of Cornell University, New York, New York, USA \\ ${ }^{9}$ Houston Methodist Hospital, Houston, Texas, USA \\ ${ }^{10}$ Columbia University Medical Center and New York Presbyterian Hospital, New York, New York, USA \\ ${ }^{11}$ University of North Carolina School of Medicine, Chapel Hill, North Carolina, USA \\ ${ }^{12}$ Cleveland Clinic, Cleveland, Ohio, USA \\ 13 University of Hong Kong Li Ka Shing Faculty of Medicine, Hong Kong, China \\ ${ }^{14}$ Radboud University Nijmegen Medical Centre, Nijmegen, The Netherlands \\ ${ }^{15}$ Asan Medical Center, Ulsan University College of Medicine, Seoul, Korea \\ ${ }^{16}$ San Raffaele H. Scientific Institute, Milan, Italy \\ ${ }^{17}$ Gundersen Lutheran Health System, La Crosse, Wisconsin, USA \\ 18 Odense University Hospital, Odense, Denmark \\ ${ }^{19}$ Feinberg School of Medicine, Northwestern University, Chicago, Illinois, USA \\ ${ }^{20}$ The University of Texas School of Medicine, Graduate School of Biomedical Sciences, Houston, Texas, USA \\ * These authors have contributed equally to this work
}

Correspondence to: Ken H. Young, email: khyoung@mdanderson.org

Keywords: diffuse large B-cell lymphoma, double-hit, MYC, BCL6, BCL2

Received: August 28, $2015 \quad$ Accepted: September 09, $2015 \quad$ Published: November 12, 2015

This is an open-access article distributed under the terms of the Creative Commons Attribution License, which permits unrestricted use, distribution, and reproduction in any medium, provided the original author and source are credited.

\section{ABSTRACT}

Double-hit B-cell lymphoma is a common designation for a group of tumors characterized by concurrent translocations of MYC and BCL2, BCL6, or other genes. The prognosis of concurrent MYC and BCL6 translocations is not well known. In this study, we assessed rearrangements and expression of MYC, BCL2 and BCL6 in 898 patients with de novo diffuse large B-cell lymphoma treated with standard chemotherapy (cyclophosphamide, doxorubicin, vincristine, and prednisone plus rituximab). Neither BCL6 translocation alone (more frequent in activated B-cell like 
diffuse large B-cell lymphoma) nor in combination with MYC translocation (observed in $\mathbf{2 . 0 \%}$ of diffuse large B-cell lymphoma) predicted poorer survival in diffuse large B-cell lymphoma patients. Diffuse large B-cell lymphoma patients with MYC/BCL6 co-expression did have significantly poorer survival, however, MYC/BCL6 co-expression had no effect on prognosis in the absence of MYC/BCL2 co-expression, and had no additive impact in $\mathrm{MYC}^{+}$/ $\mathrm{BCL2}^{+}$cases. The isolated $\mathrm{MYC}^{+} / \mathrm{BCL6}^{+} / \mathrm{BCL2}^{-}$subset, more frequent in germinal center B-cell like diffuse large B-cell lymphoma, had significantly better survival compared with the isolated $\mathrm{MYC}^{+} / \mathrm{BCL2}^{+} / \mathrm{BCL6}^{-}$subset (more frequent in activated $\mathrm{B}$-cell like diffuse large $B-c e l l$ lymphoma). In summary, diffuse large B-cell lymphoma patients with either MYC/ $B C L 6$ rearrangements or MYC/BCL6 co-expression did not always have poorer prognosis; MYC expression levels should be evaluated simultaneously; and double-hit B-cell lymphoma needs to be refined based on the specific genetic abnormalities present in these tumors.

\section{INTRODUCTION}

Diffuse large B-cell lymphoma (DLBCL) is the most common type of non-Hodgkin lymphoma and has heterogeneous biologic features. Chromosomal rearrangements, the biologic and diagnostic hallmarks of some other types of B-cell lymphoma, also occur in DLBCL. The most common chromosomal rearrangements in DLBCL are those involving chromosomal gene loci 8q24/MYC, 18q21/BCL2, and 3q27/BCL6 [1, 2]. MYC rearrangement, a disease-initiating event in Burkitt lymphoma (BL), can be observed in approximately $10 \%$ of de novo DLBCL and correlates with a poorer outcome [3-7]. However, MYC rearrangement alone may not explain the poor prognosis of patients with DLBCL that carry $M Y C$ rearrangement plus another chromosomal rearrangement. The designation double-hit lymphoma (DHL) has been used for a B-cell lymphoma carrying a $M Y C / 8 \mathrm{q} 24$ rearrangement in combination with a rearrangement involving either $B C L 2, B C L 6$, or rarely other known oncogenes $[2,8,9]$.

By far, the most common and well-studied type of DHL is characterized by concurrent $M Y C$ and $B C L 2$ rearrangements (MYC/BCL2 DHL), occurring in about 5\% of all cases of DLBCL $[10,11]$. As key regulators of cell proliferation and apoptosis, respectively, $M Y C$ and $B C L 2$ may act synergistically to drive the pathogenesis of $M Y C /$ $B C L 2$ DHL [12]. Clinically, patients with $M Y C / B C L 2$ DHL often exhibit adverse prognostic factors, such as high serum lactate dehydrogenase (LDH) level, advanced stage of disease, extranodal involvement, and a high proliferation index with a median value of $90 \%$. There is a general consensus that $M Y C / B C L 2 \mathrm{DHL}$ represents a treatment-refractory subgroup with a median survival of approximately 8 months [13-20]. Despite the dismal outcome of patients with $M Y C / B C L 2$ DHL, almost all of these tumors arise within the germinal center B cell-like (GCB) subtype, a generally favorable prognostic subtype, illustrating a discordance between clinical behavior and cell of origin (COO) subtypes $[1,15,17,21]$.

As an extension of the concept of $M Y C / B C L 2$ DHL, the concept of "double protein lymphoma (DPL)" has been developed in recent years referring to DLBCL with coexpression of MYC and BCL2 detected by immunohistochemistry (IHC), regardless of activation mechanisms. MYC/BCL2 DPL is more common than $M Y C / B C L 2$ DHL and accounts for $18-44 \%$ of DLBCL cases and might result from gene amplification, transcriptional dysregulation or both [11, 22-26]. A series of studies have shown that patients with MYC/ BCL2 DPL have a significantly poorer outcome than patients who express only one or neither protein, with a 5 -year progression-free survival (PFS) of $25 \%$ following R-CHOP treatment $[11,22]$. Interestingly, unlike $M Y C /$ $B C L 2$ DHL which is mainly observed in the GCB subtype, MYC/BCL2 DPL is more common in the activated-B celllike $(\mathrm{ABC})$ subtype and may largely contribute to inferior survival via NF- $\kappa$ B pathway activation [23].

According to the concept of DHL used currently, another type of DHL is $M Y C / B C L 6$ DHL with concurrent $M Y C$ and $B C L 6$ rearrangements $[1,2]$. However, there are far less data available for $M Y C / B C L 6$ DHL, in part because of its rarity. BCL6 is a transcriptional suppressor required for germinal center formation with numerous transcriptional targets, including the cell cycle regulator $C C N D 2$ and $M Y C$, which explains downregulation of $M Y C$ in normal germinal center B-cells [27-29]. Studies by others have suggested that BCL6 expression is associated with better survival of DLBCL patients $[24,30]$. The frequency and the prognostic impact of concurrent $M Y C / B C L 6$ rearrangements and MYC/BCL6 protein coexpression in DLBCL remain unclear.

In this study, we assessed the frequency, clinicopathologic features, and the prognostic impact of concurrent MYC/BCL6 rearrangements or MYC/BCL6 coexpression in a large cohort of de novo DLBCL patients treated with R-CHOP, in comparison to $M Y C / B C L 2$ rearrangements and MYC/BCL2 coexpression. The study evaluated the role of each genetic translocation separately and in combinations, providing reliable conclusion and practical recommendations for diagnostic workup and prognostic prediction. 
Table 1: Frequencies of $M Y C, B C L 2$ and $B C L 6$ gene translocations and protein overexpression, and multivariate survival analysis

\begin{tabular}{|c|c|c|c|c|c|c|c|c|}
\hline & Overall & GCB & $\mathbf{A B C}$ & GCB vs ABC & OS & & PFS & \\
\hline & $\mathrm{n} / \mathrm{n}(\%)$ & $\mathrm{n} / \mathrm{n}(\%)$ & $\mathrm{n} / \mathrm{n}(\%)$ & $P$ value & HR $(95 \%$ CI $)$ & $P$ value & HR $(95 \%$ CI $)$ & $P$ value \\
\hline$M Y C$ translocation & $71 / 600(11.8 \%)$ & $51 / 314(16.2 \%)$ & $20 / 284(7.0 \%)$ & .0005 & $1.36(0.83-2.23)$ & .22 & $1.26(0.79-2.01)$ & .34 \\
\hline$B C L 2$ translocation & $94 / 690(13.6 \%)$ & $\underline{85 / 360(23.6 \%)}$ & $9 / 328(2.7 \%)$ & $<.0001$ & $1.39(0.86-2.24)$ & .17 & $1.34(0.86-2.09)$ & .20 \\
\hline$B C L 6$ translocation & $145 / 628(23.1 \%)$ & $\overline{59 / 338(17.5 \%)}$ & $\underline{86 / 286(30.1 \%)}$ & .0002 & $1.06(0.70-1.61)$ & .77 & $1.13(0.77-1.66)$ & .53 \\
\hline $\mathrm{MYC}^{+}$expression & $249 / 825(30.2 \%)$ & $121 / 430(28.1 \%)$ & $127 / 390(32.6 \%)$ & .17 & $1.89(1.26-2.84)$ & .002 & $1.85(1.26-2.71)$ & .002 \\
\hline $\mathrm{BCL} 2^{+}$expression & $439 / 849(51.7 \%)$ & $194 / 439(44.2 \%)$ & $245 / 406(60.3 \%)$ & $<.0001$ & $1.67(1.14-2.46)$ & .009 & $1.70(1.19-2.42)$ & .004 \\
\hline BCL6 $^{+}$expression & $555 / 887(62.6 \%)$ & $\underline{350 / 462(75.8 \%)}$ & $\overline{204 / 424(48.1 \%)}$ & $<.0001$ & $0.67(0.45-1.00)$ & .048 & $0.47(0.40-0.89)$ & .016 \\
\hline$M Y C+/ B C L 2+$ double-hit & $20 / 710(2.8 \%)$ & $\underline{19 / 359(5.3 \%)}$ & $1 / 349(0.3 \%)$ & $<.0001$ & $3.38(1.75-6.52)$ & $<.0001$ & $3.04(1.63-5.67)$ & $<.0001$ \\
\hline$M Y C+/ B C L 6+$ concurrent translocation & $14 / 683(2.0 \%)$ & $9 / 356(2.5 \%)$ & $5 / 323(1.5 \%)$ & .37 & $0.67(0.23-1.97)$ & .47 & $0.85(0.33-2.21)$ & .74 \\
\hline$B C L 2+/ B C L 6+$ concurrent translocation & $21 / 718(2.9 \%)$ & $\underline{18 / 371(4.9 \%)}$ & $3 / 341(0.9 \%)$ & .0045 & $0.47(0.16-1.39)$ & .14 & $0.52(0.20-1.33)$ & .17 \\
\hline $\mathrm{MYC}^{+} / \mathrm{BCL}^{+}$double-positive & $146 / 831(17.6 \%)$ & $62 / 434(14.3 \%)$ & $\underline{84 / 390(21.5 \%)}$ & .0079 & $2.54(1.65-3.94)$ & $<.0001$ & $2.92(1.91-4.47)$ & $<.0001$ \\
\hline $\mathrm{MYC}^{+} / \mathrm{BCL}^{+}{ }^{-}$co-expression & $178 / 821(21.7 \%)$ & $97 / 434(22.4 \%)$ & $81 / 413(19.6 \%)$ & .35 & $1.02(0.65-1.58)$ & .94 & $0.85(0.56-1.30)$ & .46 \\
\hline $\mathrm{BCL}^{+} / \mathrm{BCL}^{+}{ }^{+}$co-expression & $282 / 845(33.4 \%)$ & $151 / 443(34.1 \%)$ & $131 / 415(31.6 \%)$ & .47 & $1.01(0.68-1.49)$ & .97 & $0.90(0.62-1.30)$ & .58 \\
\hline $\mathrm{MYC}^{+} / \mathrm{BCL}^{+} / \mathrm{BCL}^{-}$ & $43 / 871(4.9 \%)$ & $13 / 460(2.8 \%)$ & $\underline{30 / 403(7.4 \%)}$ & .0019 & $1.60(1.01-2.54)$ & .046 & $2.16(1.39-3.34)$ & .001 \\
\hline $\mathrm{MYC}^{+} / \mathrm{BCL}^{+} / \mathrm{BCL}^{-}$ & $75 / 850(8.8 \%)$ & $49 / 434(11.3 \%)$ & $26 / 412(6.3 \%)$ & .011 & $0.87(0.54-1.40)$ & .56 & $0.86(0.58-1.34)$ & .51 \\
\hline $\begin{array}{c}\mathrm{MYC}^{+} / \mathrm{BCL}^{+} / \mathrm{BCL}^{+} \\
\text {(triple-positive) }\end{array}$ & $101 / 829(12.2 \%)$ & $47 / 432(10.9 \%)$ & $54 / 390(13.8 \%)$ & .20 & $2.57(1.86-3.56)$ & $<.0001$ & $2.41(1.77-3.28)$ & $<.0001$ \\
\hline
\end{tabular}

Abbreviations: OS, overall survival; PFS, progression-free survival; HR, hazard ratio; CI, confidence interval.

Note: (1) Not all the patients had experiment results available for all three genes (MYC/BCL2/BCL6) or protein mostly due to tissue exhaustion. Total patient numbers for particular biomarkers are listed. For defined combination biomarkers (double-hit/concurrent translocation or double positive/co-expression), total case numbers are more than those for single markers because some cases had only one gene/protein (as a component of the defined biomarker combinations) data available and the results were negative. For example, cases known to have no $M Y C$ translocation but without $B C L 2$ translocation status known are included as non $M Y C+/ B C L 2+$ double-hit cases during frequency calculation.

(2) For multivariate analyses, four Cox models including different prognostic factors were used. The first model included 4 clinical parameters (International Prognostic Index, gender, B-symptoms, and tumor size), $M Y C, B C L 2$, and $B C L 6$ translocation status, and MYC, BCL2, and BCL6 protein expression levels as variables (totally 10 factors) and the results are as shown in the top six rows. The second model included clinical parameters, and status for $M Y C+/ B C L 2+, M Y C+/ B C L 6+, B C L 2+/ B C L 6+, \mathrm{MYC}^{+} / \mathrm{BCL}^{+}, \mathrm{MYC}^{+} / \mathrm{BCL}^{+}{ }^{+}$and $\mathrm{BCL}^{+} / \mathrm{BCL}^{+}$(totally 10 factors) and the results are shown in the 7 th-12th rows. The third models included clinical parameters, and status for "MYC $/ \mathrm{BCL}^{+} / \mathrm{BCL}^{-}$and $\mathrm{MYC}^{+} / \mathrm{BCL}^{+} / \mathrm{BCL}^{-}$(totally 6 factors) and the results are shown in the $13-14$ rows. The fourth model included clinical parameters and $\mathrm{MYC}^{+} / \mathrm{BCL}^{+} / \mathrm{BCL}^{+}$as a factor and the results are shown in the last row.

\section{RESULTS}

\section{Overall frequency and distribution}

The median age of the study population was 64 years (range, 16-95). The median follow-up time was 58.9 months (range, 1-187 months). Among the 898 cases, $469(52 \%)$ were GCB and $429(48 \%)$ were determined to be GCB and ABC subtype, respectively. The complete response rate to $\mathrm{R}-\mathrm{CHOP}$ therapy was $75 \%$. As shown in Table 1, rearrangements of $M Y C, B C L 2$, and $B C L 6$ were detected in $71(11.8 \%)$ of $600,94(13.6 \%)$ of 690 , and 145 (23.1\%) of 628 cases, respectively. MYC and BCL2 rearrangements were detected predominantly in GCB subtype ( $P=0.0005$ and $P<0.0001$, respectively) whereas $B C L 6$ rearrangement was more frequently observed in the $\mathrm{ABC}$ subtype $(P=0.0002) . M Y C / B C L 2, M Y C /$ $B C L 6$, and $B C L 2 / B C L 6$ concurrent rearrangements were identified in $20(2.8 \%), 14(2 \%)$, and $21(2.9 \%)$ patients, respectively. Both $M Y C / B C L 2$ and $B C L 2 / B C L 6$ concurrent rearrangements were observed mostly in the GCB subtype $(M Y C+/ B C L 2+: P<0.0001 ; B C L 2+/ B C L 6+: P=0.0045)$ whereas $M Y C / B C L 6$ concurrent rearrangements were observed in two $\mathrm{COO}$ subtypes ( $9 \mathrm{GCB}, 5 \mathrm{ABC}$ ) without significantly difference in frequency $(P=0.37)$.

Using immunohistochemistry 249 (30.2\%), 439 $(51.7 \%)$, and $555(62.6 \%)$ patients had high levels of MYC $(\geq 70 \%)$, BCL2 $(\geq 70 \%)$, and BCL6 ( $>50 \%)$ expression, respectively. MYC expression was similarly distributed between GCB and ABC subtypes $(P=0.17)$ whereas BCL2 and BCL6 expression were significantly more common in the $\mathrm{ABC}$ and $\mathrm{GCB}$ subtypes, respectively (both $P<0.0001$ ), in contrast to the association of their gene translocations with $\mathrm{GCB}$ and $\mathrm{ABC}$ subtype respectively. $\mathrm{MYC}^{+} / \mathrm{BCL}^{+}, \mathrm{MYC}^{+} / \mathrm{BCL}^{+}$, and $\mathrm{BCL}^{+} /$ $\mathrm{BCL}^{+}$coexpression were observed in $146(17.6 \%), 178$ (21.7\%), and $282(33.4 \%)$ cases, respectively. Unlike the predominance of $\mathrm{MYC}^{+} \mathrm{BCL} 2^{+}$coexpression in the $\mathrm{ABC}$ subtype $(P=0.0079)$, both $\mathrm{MYC}^{+} / \mathrm{BCL}^{+}$and $\mathrm{BCL} 2^{+} /$ $\mathrm{BCL}^{+}$coexpression were equally distributed between the two COO subtypes ( $P=0.35$ and $P=0.47$, respectively). All MYC protein positive patients were further stratified into three subgroups: $\mathrm{MYC}^{+} / \mathrm{BCL}^{+} / \mathrm{BCL}^{-}\left(\mathrm{MYC}^{+} / \mathrm{BCL}^{+}\right.$ coexpression, BCL6 $), \mathrm{MYC}^{+} / \mathrm{BCL}^{+} / \mathrm{BCL}^{-}\left(\mathrm{MYC}^{+} /\right.$ $\mathrm{BCL}^{+}$coexpression, $\mathrm{BCL} 2^{-}$) and $\mathrm{MYC}^{+} / \mathrm{BCL}^{+} / \mathrm{BCL}^{+}$ coexpression. The $\mathrm{MYC}^{+} \mathrm{BCL} 2^{+} \mathrm{BCL} 6^{-}$subgroup was predominantly of $\mathrm{ABC}$ subtype $(P=0.0019)$, whereas the $\mathrm{MYC}^{+} \mathrm{BCL} 6^{+} \mathrm{BCL} 2^{-}$subgroup was more commonly of 
GCB subtype $(P=0.011)$ (Table 1$)$.

\section{Clinicopathologic features of DLBCL with concurrent rearrangement and coexpression}

The clinicopathologic features of patients in the study cohort with or without concurrent gene rearrangements and protein coexpression are listed in Table 2. DLBCL patients with $M Y C / B C L 2$ rearrangements more frequently had large tumors $(P=0.02)$ and a lower complete response rate $(P=0.0033)$, and commonly the tumors were of GCB subtype $(P<0.0001)$. No clinicopathologic features were significantly different between DLBCL patients with concurrent MYC/BCL6 rearrangements versus patients without $M Y C / B C L 6$ concurrent rearrangement, although larger tumor size was of borderline significance $(P=0.058)$.

Patients with $\mathrm{MYC}^{+} / \mathrm{BCL}^{+}$coexpression were more often of older age $(P=0.0016)$ and more often had advanced disease stage $(P<0.0001)$, extranodal involvement $(P=0.0026)$, large tumor size $(P=0.03)$, International Prognostic Index score $>2(P<0.0001)$, low complete response rate $(P=0.0071)$, and high $\mathrm{Ki}$ -
$67(P=0.0002)$, and the lymphoma was more often of ABC subtype $(P=0.0079)$. Patients with $\mathrm{MYC}^{+} / \mathrm{BCL}^{+}$ coexpression were associated with advanced disease stage $(P=0.015)$, extranodal sites $(P=0.011)$, low complete response rate $(P=0.0023)$ and high Ki-67 index $(P=$ 0.0017). When $\mathrm{MYC}^{+} / \mathrm{BCL}^{+} / \mathrm{BCL}^{-}$and $\mathrm{MYC}^{+} / \mathrm{BCL}^{+} /$ BCL2- subgroups were isolated from the $\mathrm{MYC}^{+} / \mathrm{BCL}^{+}$ and $\mathrm{MYC}^{+} / \mathrm{BCL}^{+}$patients respectively, $\mathrm{MYC}^{+} / \mathrm{BCL}^{+} /$ BCL6 tumors were more often of $\mathrm{ABC}$ subtype, whereas $\mathrm{MYC}^{+} / \mathrm{BCL}^{+} / \mathrm{BCL} 2^{-}$tumors were more commonly of GCB subtype $(P=0.0003)$ (Table 2$)$.

\section{Prognostic impact of concurrent rearrangements of $M Y C, B C L 2$, and $B C L 6$ in DLBCL}

We first assessed the prognostic impact of rearrangements of $M Y C, B C L 2$, and $B C L 6$ in DLBCL (Figure 1 and Supplementary Figure S1). Both $M Y C$ and $B C L 2$ rearrangements correlated to a poorer survival in the whole cohort $(P=0.003$ for $M Y C$, Figure 1A; $P=$ 0.046 for $B C L 2$, Figure 1B) and in the GCB subtype $(P<$ 0.0001 for $M Y C$, Figure 1D; $P<0.0009$ for $B C L 2$, Figure $1 \mathrm{E}$ ) but not in the $\mathrm{ABC}$ subtype (Figure $1 \mathrm{G}-1 \mathrm{H}$ ). BCL6
A

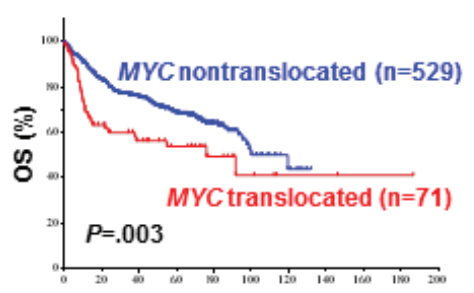

D

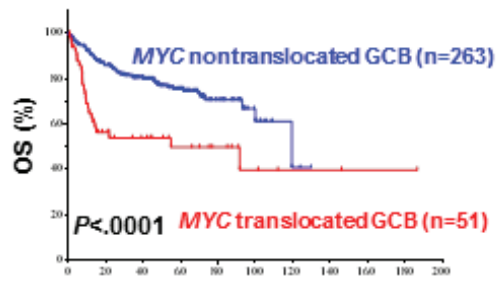

G

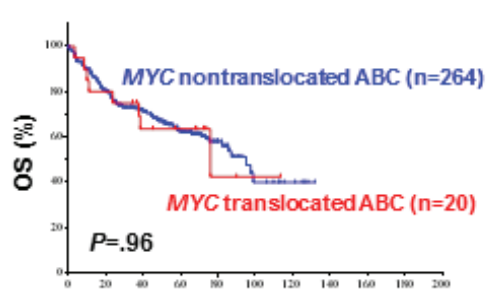

Months
B

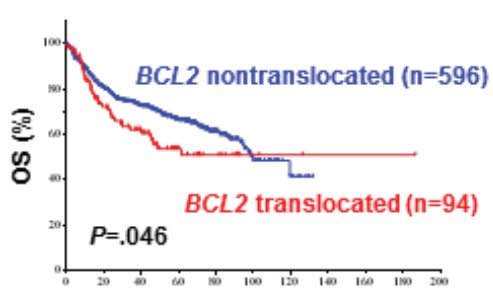

E

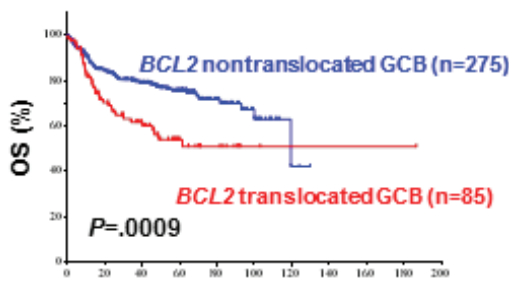

$\mathrm{H}$

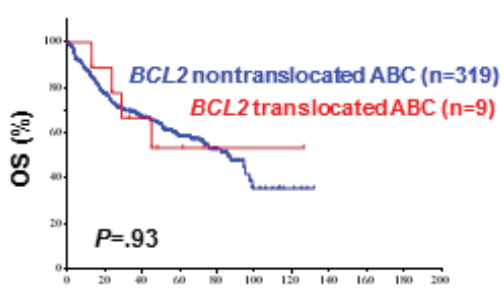

Months
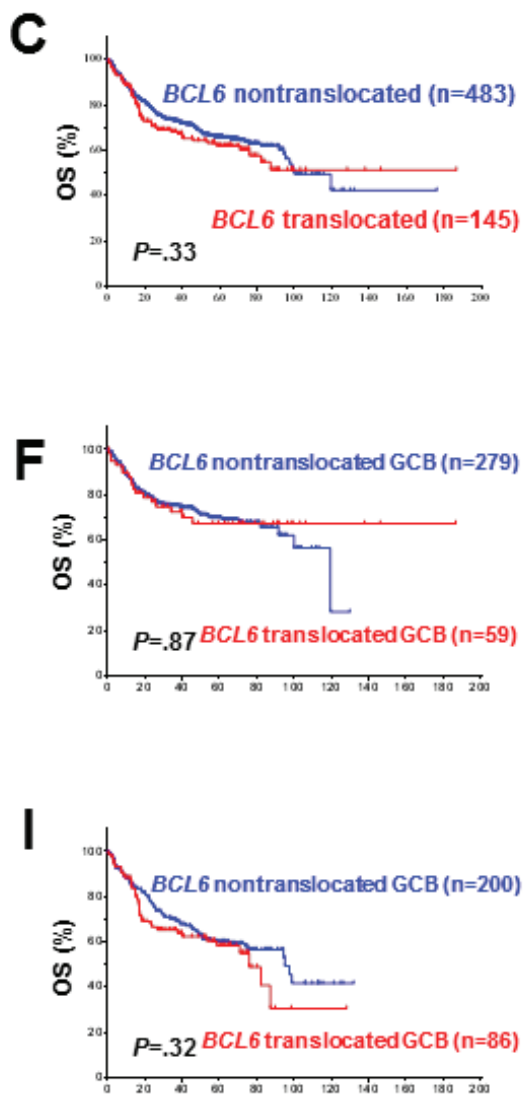

Months

Figure 1: Univariate analysis for patients with DLBCL with $M Y C, B C L 2$, and $B C L 6$ rearrangemnts in the overall-, GCB, and ABC groups. A.-B., D.-E, G.-H. $M Y C$ and $B C L 2$ rearrangements correlated with significantly poorer overall survival in overall and GCB- but not ABC-DLBCL. C., F., I. BCL6 translocation did not correlate with poorer overall survival. 
translocation, by contrast, did not correlate with poorer survival for either the whole cohort $(P=0.33$, Figure 1C) or in the $\operatorname{GCB}(P=0.87$, Figure $1 \mathrm{~F})$ and $\mathrm{ABC}(P=0.32$, Figure 1I) subtypes.

We then assessed the prognostic impact of concurrent rearrangements in DLBCL. Patients with MYC/

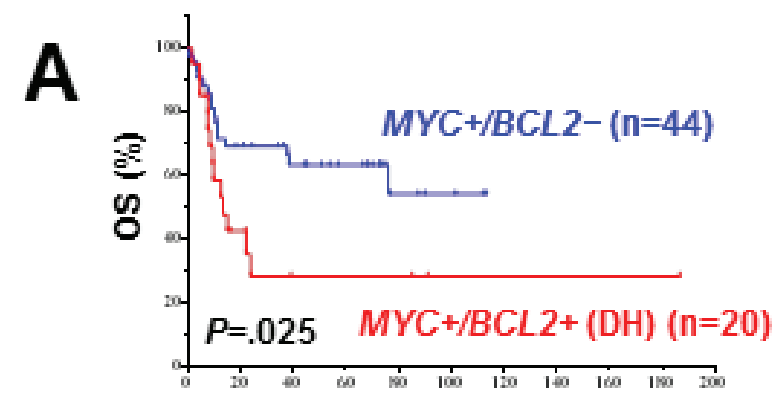

C

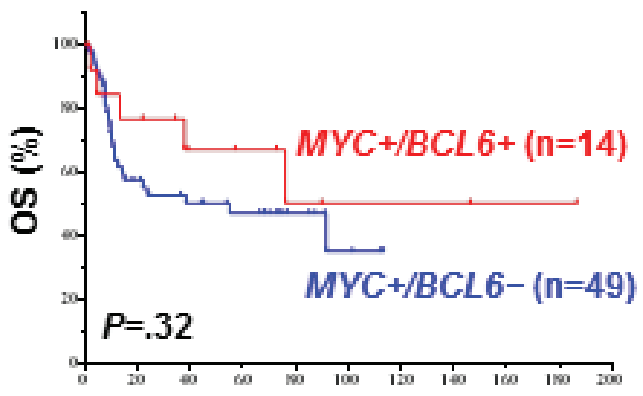

E
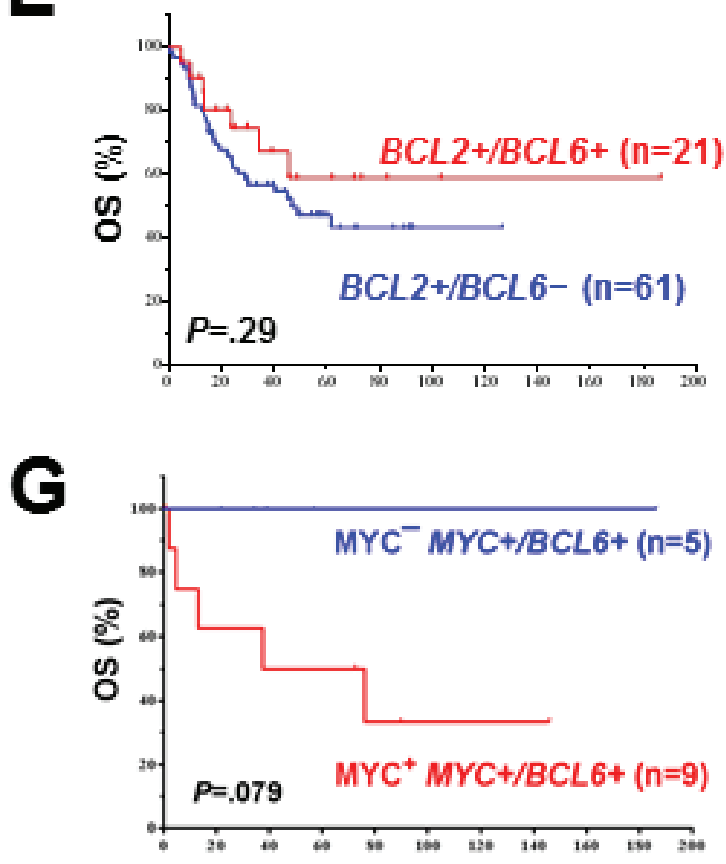

Months
$B C L 2$ translocations had a worse survival than patients with $M Y C$ rearrangement alone (overall survival [OS]: $P$ $=0.025$; PFS: $P=0.012$, Figure 2A-2B). However, no difference was observed in OS and PFS between DLBCL patients with $M Y C / B C L 6$ rearrangement versus DLBCL patients with only $M Y C$ rearrangement (Figure 2C-2D).
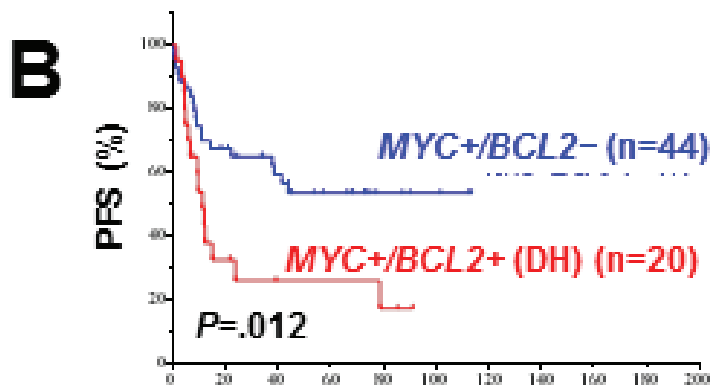

D

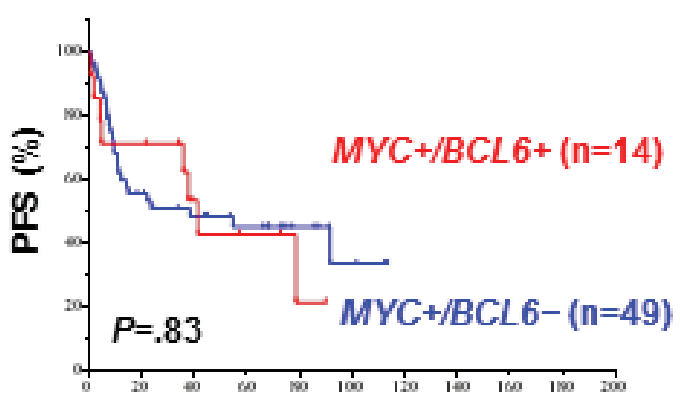

E

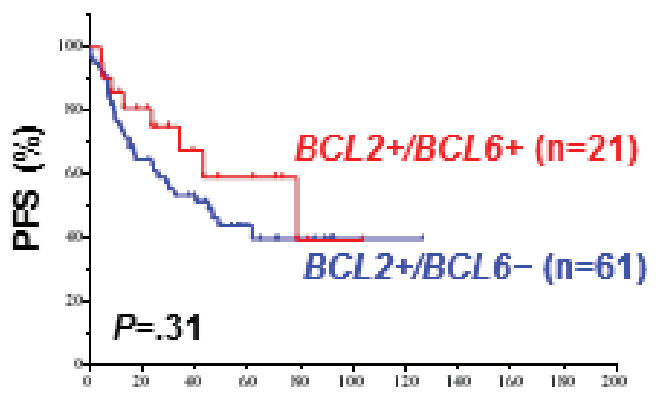

H

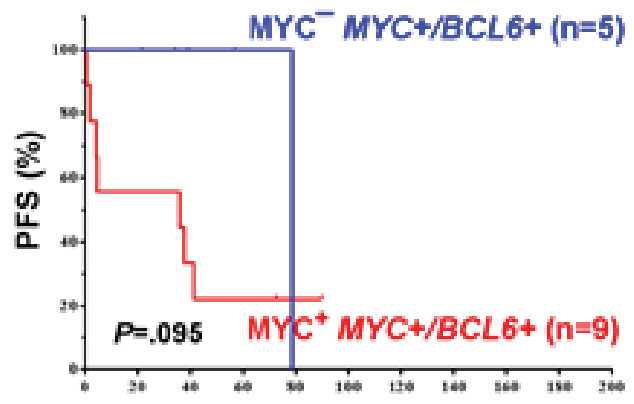

Months

Figure 2: A.-B. The prognostic significance of $M Y C$ rearrangements in DLBCL depends on $B C L 2$ rearrangement. C.-D. BCL6 rearrangement had no additive effect to $M Y C$ rearrangements. E.-F. BCL6 translocation had no additive effect to BCL2 rearrangements. G.-H. MYC expression levels appeared to impact the survival of $M Y C+/ B C L 6+$ rearranged DLBCL with marginal $P$ values probably due to the small case numbers. 
Table 2: Clinical characteristics of patients with concurrent MYC, BCL2 or BCL6 translocations and MYC, BCL2 or BCL6 protein co-expression

\begin{tabular}{|c|c|c|c|c|c|c|c|c|c|c|c|c|c|c|c|}
\hline Parameters & $\begin{array}{l}M Y C+/ B C L 2+ \\
(\mathbf{D H})\end{array}$ & $\begin{array}{l}\text { Non- } \\
M Y C+/ B C L 2+\end{array}$ & $P$ & $M Y C+/ B C L 6+$ & $\begin{array}{l}\text { Non- } \\
\text { MYC+/BCL } 6+\end{array}$ & $P$ & $\underset{\left(\mathrm{DP}^{2}\right)}{\mathrm{MYC}^{+} / \mathrm{BCL}^{+}}$ & $\begin{array}{l}\text { Non- } \\
\text { MYC }^{+} / \mathbf{B C L 2}^{+}\end{array}$ & $P$ & $\mathrm{MYC}^{+} / \mathrm{BCL}^{+}$ & $\begin{array}{l}\text { Non- } \\
\text { MYC }^{+} / \mathbf{B C L}^{+}\end{array}$ & $P$ & $\begin{array}{l}\text { MYC'/BCL2 } \\
\text { BCL6 }\end{array}$ & $\underset{\text { BCL2 }}{\mathrm{MYC}^{+} / \mathrm{BCL}^{+}}$ & $P$ \\
\hline & $\mathrm{N}(\%)$ & $\mathrm{N}(\%)$ & & $\mathrm{N}(\%)$ & $\mathrm{N}(\%)$ & & $\mathrm{N}(\%)$ & $N(\%)$ & & $\mathrm{N}(\%)$ & $\mathrm{N}(\%)$ & & $\mathrm{N}(\%)$ & $\mathrm{N}(\%)$ & \\
\hline \multicolumn{16}{|l|}{ Age } \\
\hline$<60$ & $7(35)$ & $254(39.9)$ & .73 & $4(30.8)$ & $253(38.8)$ & .51 & $39(28.7)$ & $285(43.2)$ & .0016 & $61(36.5)$ & $262(40.4)$ & .36 & $14(34.1)$ & $36(50)$ & .10 \\
\hline$\geq 60$ & $13(65)$ & $401(60.1)$ & & $9(69.2)$ & $381(61.2)$ & & $97(71.3)$ & $374(56.8)$ & & $106(63.5)$ & $386(59.6)$ & & $27(65.9)$ & $36(50)$ & \\
\hline \multicolumn{16}{|l|}{ Gender } \\
\hline $\mathrm{F}$ & $6(30)$ & $266(39.6)$ & .35 & $7(53.8)$ & $252(40.4)$ & .30 & $61(44.5)$ & $272(41.2)$ & .47 & $74(44)$ & $266(41)$ & .47 & $17(40.5)$ & $30(41.1)$ & .95 \\
\hline M & $14(70)$ & $392(60.4)$ & & $6(46.2)$ & $385(59.6)$ & & $76(55.5)$ & $388(58.8)$ & & $94(56)$ & $383(59)$ & & $25(59.5)$ & $43(58.9)$ & \\
\hline \multicolumn{16}{|l|}{ Stage } \\
\hline I-II & $5(27.8)$ & $292(45.2)$ & .13 & $5(41.7)$ & $278(45.8)$ & .81 & $40(30.5)$ & $318(49.9)$ & $<.0001$ & $60(37)$ & $299(47.7)$ & .015 & $16(39)$ & $36(50)$ & .26 \\
\hline III-IV & $13(72.2)$ & $345(54.8)$ & & $7(58.3)$ & $337(54.2)$ & & $91(69.5)$ & $319(50.1)$ & & $102(63)$ & $328(52.3)$ & & $25(61)$ & $36(50)$ & \\
\hline \multicolumn{16}{|c|}{ B-symptoms } \\
\hline № & $11(61.1)$ & $372(61.3)$ & .98 & $6(50)$ & $357(60.9)$ & .43 & $70(55.6)$ & $393(63.9)$ & .078 & $96(60.8)$ & $377(62.6)$ & .67 & $22(53.7)$ & $48(66.7)$ & .17 \\
\hline Yes & $7(38.9)$ & $239(38.7)$ & & $6(50)$ & $225(39.1)$ & & $56(44.4)$ & $222(36.1)$ & & $62(39.2)$ & $225(37.4)$ & & $19(46.3)$ & $24(33.3)$ & \\
\hline \multicolumn{16}{|l|}{ LDH } \\
\hline Normal & $5(27.8)$ & $244(39.5)$ & .25 & $4(30.8)$ & $226(41.1)$ & .52 & $44(35.2)$ & $243(40.5)$ & .27 & $59(37.6)$ & $239(40.6)$ & .48 & $12(31.6)$ & $27(38.6)$ & .47 \\
\hline Elevated & $13(72.2)$ & $349(60.5)$ & & $9(69.2)$ & $346(58.9)$ & & $81(64.8)$ & $357(59.5)$ & & $98(62.4)$ & $349(59.4)$ & & $26(68.4)$ & $43(61.4)$ & \\
\hline \multicolumn{16}{|c|}{ \# of extranodal sites } \\
\hline $0-1$ & $12(63.2)$ & $481(77.4)$ & .16 & $7(63.6)$ & $468(77)$ & .28 & $88(67.7)$ & $501(79.8)$ & .0026 & $113(70.2)$ & $490(79.5)$ & .011 & $28(70)$ & $53(74.6)$ & .60 \\
\hline$\geq 2$ & $7(36.8)$ & $144(22.6)$ & & $4(36.4)$ & $137(23)$ & & $42(32.3)$ & $127(20.2)$ & & $48(29.8)$ & $126(20.5)$ & & $12(30)$ & $18(25.4)$ & \\
\hline \multicolumn{16}{|l|}{ ECOG } \\
\hline $0-1$ & $14(77.8)$ & $471(82.5)$ & .62 & $7(63.6)$ & $456(82.3)$ & .11 & $93(75)$ & $486(84.4)$ & .012 & $119(76.8)$ & $470(83.3)$ & .06 & $29(76.3)$ & $56(81.2)$ & .55 \\
\hline$\geq 2$ & $4(22.2)$ & $101(17.5)$ & & $4(36.4)$ & $97(17.7)$ & & $31(25)$ & $90(15.6)$ & & $36(23.2)$ & $94(16.7)$ & & $9(23.7)$ & $13(18.8)$ & \\
\hline \multicolumn{16}{|c|}{ Size of largest tumor } \\
\hline$<5 \mathrm{~cm}$ & $4(25)$ & $273(54)$ & .02 & $2(22.2)$ & $259(54.4)$ & .058 & $50(45)$ & $288(56.4)$ & .03 & $67(48.2)$ & $268(56.1)$ & .10 & $11(31.4)$ & $28(45.2)$ & .19 \\
\hline$\geq 5 \mathrm{~cm}$ & $12(75)$ & $229(46)$ & & $7(77.8)$ & $221(45.6)$ & & $61(55)$ & $223(43.6)$ & & $72(51.8)$ & $210(43.9)$ & & $24(68.6)$ & $34(54.8)$ & \\
\hline \multicolumn{16}{|l|}{ IPI score } \\
\hline $0-2$ & $8(44.4)$ & $377(59.8)$ & .17 & $6(50)$ & $355(60.5)$ & .50 & $56(42.7)$ & $401(65.1)$ & $<.0001$ & $81(49.7)$ & $381(63.2)$ & .0018 & $19(47.5)$ & $44(61.1)$ & .16 \\
\hline 3-5 & $10(55.6)$ & $246(40.2)$ & & $6(50)$ & $239(39.5)$ & & $75(57.3)$ & $215(34.9)$ & & $82(50.3)$ & $222(36.8)$ & & $21(52.5)$ & $28(38.9)$ & \\
\hline \multicolumn{16}{|c|}{ Therapy response } \\
\hline CR & $10(55)$ & $487(75.3)$ & .026 & $8(66.7)$ & $464(76.3)$ & .48 & $79(48.2)$ & $501(78.8)$ & $<.0001$ & $108(65.9)$ & $484(77.4)$ & .0023 & $25(61)$ & $55(77.5)$ & .06 \\
\hline PR & 3 & 80 & & 2 & 80 & & 59 & 70 & & 31 & 70 & & 9 & 8 & \\
\hline SD & 2 & 27 & & 1 & 24 & & 9 & 23 & & 7 & 30 & & 4 & 2 & \\
\hline PD & 4 & 44 & & 1 & 47 & & 17 & 42 & & 18 & 41 & & 3 & 6 & \\
\hline \multicolumn{16}{|c|}{ Cell-of-origin } \\
\hline $\mathrm{GCB}$ & $19(95)$ & $340(52.2)$ & $<.0001$ & $9(64.3)$ & $347(49.4)$ & .43 & $62(42.5)$ & $372(54.9)$ & .0079 & $97(54.5)$ & $337(50.4)$ & .35 & $13(30.2)$ & $49(65.3)$ & .0003 \\
\hline $\mathrm{ABC}$ & $1(5)$ & $348(47.8)$ & & $5(35.7)$ & $318(50.6)$ & & $84(57.5)$ & $306(45.1)$ & & $81(45.5)$ & $332(49.6)$ & & $30(69.8)$ & $26(34.7)$ & \\
\hline \multicolumn{16}{|c|}{ Ki-67 index } \\
\hline$<70 \%$ & $5(45.5)$ & $137(32.5)$ & .52 & $3(37.5)$ & $125(33.1)$ & .72 & $19(19.4)$ & $170(39.2)$ & .0002 & $29(23.8)$ & $159(39.6)$ & .0017 & $6(19.4)$ & $16(28.6)$ & .44 \\
\hline $270 \%$ & $6(54.5)$ & $277(67.5)$ & & $5(62.5)$ & $260(66.9)$ & & $79(80.6)$ & $264(60.8)$ & & $93(76.2)$ & $243(60.4)$ & & $25(80.6)$ & $40(71.4)$ & \\
\hline \multicolumn{16}{|c|}{ TP53 mutation } \\
\hline WT & $8(72.7)$ & $301(78.8)$ & .71 & $7(100)$ & $276(78.2)$ & .35 & $62(71.3)$ & $311(78.9)$ & .12 & $81(75.7)$ & $284(78.0)$ & .60 & $20(76.9)$ & $40(83.3)$ & .54 \\
\hline MUT & $3(27.3)$ & $81(21.2)$ & & $0(0)$ & $77(21.8)$ & & $25(28.7)$ & $83(21.1)$ & & $26(24.3)$ & $80(22.0)$ & & $6(23.1)$ & $8(16.7)$ & \\
\hline
\end{tabular}

There was also no difference in OS and PFS between patients with DLBCL with BCL2/BCL6 rearrangement versus DLBCL with only $B C L 2$ rearrangement (Figure 2E-2F). Notably the survival of patients with $M Y C / B C L 6$ rearrangement appeared to be affected by MYC expression levels (Figure 2G-2H).

The prognostic differences between patients with concurrent rearrangements of $M Y C / B C L 2, M Y C / B C L 6$, $B C L 2 / B C L 6$ versus the remaining DLBCL patients are shown in Figure 3. Only concurrent $M Y C / B C L 2$ rearrangements correlated with significantly poorer survival (Figure 3A-3B). Additional BCL6 translocation (triple-hit, $n=5,26 \%$ of $19 M Y C+/ B C L 2+$ cases with $B C L 6$ translocation status available) had no synergistic effect with concurrent $M Y C / B C L 2$ rearrangements and, on the contrary, attenuated the adverse impact of concurrent $M Y C / B C L 2$ rearrangements (Figure $3 \mathrm{G}-3 \mathrm{H}$ ).

\section{Prognostic impact of coexpression of MYC, BCL2, and BCL6 in DLBCL}

The prognostic impact of protein expression of MYC, BCL2, and BCL6 is shown in Figure 4 and Supplementary Figure S2. BCL6 expression in DLBCL did not correlate with poorer patient survival, either in the whole group or in $\mathrm{COO}$ subtypes (Figure $4 \mathrm{C}$, 4F, and $4 \mathrm{I})$. In contrast, $\mathrm{MYC}^{+}$or BCL2 ${ }^{+}$expression in DLBCL correlated with significantly poorer survival for the overall patient cohort $(P<0.0001$, Figure 4A-4B) and for patients with GCB (MYC $: P<0.0001$, Figure 4D; BCL2 ${ }^{+}: P=$ 0.004 , Figure $4 \mathrm{E}$ ) and $\mathrm{ABC}$ subtypes of DLBCL $\left(\mathrm{MYC}^{+}\right.$: $P=0.032$, Figure 4G; BCL2 ${ }^{+}: P<0.0001$, Figure 4H).

Our results further showed that $\mathrm{MYC}^{+} / \mathrm{BCL}^{+}$ $(P<0.0001$, Figure 5A, Supplementary Figure S3A $)$, $\mathrm{MYC}^{+} / \mathrm{BCL6}^{+}$(OS: $P=0.0001$, Figure $5 \mathrm{C}$; PFS: $P$ $=0.0002$, Supplementary Figure $\mathrm{S} 3 \mathrm{C}$ ), and $\mathrm{BCL}^{+} /$ BCL6 $^{+}$(OS: $P=0.014$, Figure 5E; PFS: $P=0.033$, Supplementary Figure S3E) coexpression correlated with significantly poorer survival in the overall cohort. The inferior survival of patients $\mathrm{MYC}^{+} / \mathrm{BCL}^{+}$and $\mathrm{MYC}^{+} /$ BCL6 ${ }^{+}$DLBCL compared with all other DLBCL patients was significant for both the $\mathrm{GCB}$ and $\mathrm{ABC}$ subtypes, whereas $\mathrm{BCL}^{+} / \mathrm{BCL}^{+}$only correlated with poorer OS for patients with ABC-DLBCL (Supplementary Figure S4). MYC expression showed dependence and synergy only with BCL2 expression (Figure 5B, Supplementary Figure S3B); BCL6 expression had no additive adverse impact in patients with $\mathrm{MYC}^{+}, \mathrm{BCL}^{+}$or $\mathrm{MYC}^{+} / \mathrm{BCL}^{+}$ DLBCL (Figure 5D, 5F-5G, Supplementary Figure S3D, 
Table 3: GEP signatures of $M Y C / B C L 2$ double-hit lymphoma, isolated $\mathrm{MYC}^{+} \mathbf{B C L 2}^{+}$(i.e., BCL6- DPL) and MYC ${ }^{+}$BCL2 $\mathrm{BCL}^{+}$(i.e., BCL2-DPL)

\begin{tabular}{|c|c|c|}
\hline \multicolumn{3}{|c|}{ A. $M Y C+/ B C L 2+$ double-hit $v s$ others (false discovery rate $<.01)$} \\
\hline Functional categories & Upregulated genes & Downregulated genes \\
\hline Signaling & BMP3, SWAP70, CELSRI & PLA2G7, DOCK10, RNF149 \\
\hline Cell proliferation and growth & STRBP, MUC4 & \\
\hline Transcriptional regulation & ZNF280D, DIP2C & PRDMI \\
\hline Metabolism & $\begin{array}{l}\text { RIMKLB, UGT8, PLA2G12A, SLC25A27, CYP39A1, C7orf10, } \\
\text { ENPP3, HPGD }\end{array}$ & \\
\hline Cell death & & TMEM49, CFLAR, CARDI6/CASP1 \\
\hline Immune response & NCR3LG1 & \\
\hline Cell adhesion, extracellular matrix, migration & MYO3B & SLAMF7, SIGLEC10/12, TPM4, SRGN \\
\hline microRNA & & MIR21 \\
\hline Others & $\begin{array}{l}\text { TPD52, C4orf34, FLJ41455, XKR6, FAM53B, TMEM156, } \\
\text { CEACAM7 }\end{array}$ & $F L C N$ \\
\hline \multicolumn{3}{|c|}{ B. MYC $^{+} \mathrm{BCL2}^{+} \mathrm{BCL6}^{-}$vs $\mathrm{MYC}^{+} \mathrm{BCL2}^{-} \mathrm{BCL6}^{+}$(false discovery rate <.05) } \\
\hline & ${\text { Upregulated in } \mathrm{MYC}^{+} \mathrm{BCL2}^{+} \mathrm{BCL6}^{-}}^{-}$ & 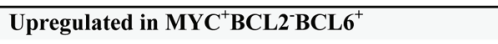 \\
\hline $\begin{array}{l}\text { BCR signaling, receptors, antigen, modulators, } \\
\text { transducers }\end{array}$ & CCR7, CYSLTR1, PRSS 21 & $\begin{array}{l}\text { STAP1, SORL1, RFTN1, GNA13, SWAP70, } \\
\text { ANKRD13A, PIK3CG }\end{array}$ \\
\hline $\begin{array}{l}\text { Proliferation, cell cycle, , gene expression DNA } \\
\text { replication }\end{array}$ & SUB1, ZBTB32, LIMD1, C16orf53 & $\begin{array}{l}\text { BCL6, MYBL1, NEK6, BRWD1, SFRS15, HMGN1, } \\
\text { TMPO }\end{array}$ \\
\hline Apoptosis & $B C L 2, C A S P 10$ & DNAJC10 \\
\hline DNA repair & & MSH6 \\
\hline Metabolism & $A L D H 4 A 1$ & $B P N T 1$ \\
\hline Cell shape, cytoskeleton, microtubes, migration & $B B I P 10$ & MARCKSL1, VNN2, OSBPL3, ACTR2 \\
\hline Unknown function & LOC100289094 & C17orf99, KIAA0746, ZNF608 \\
\hline
\end{tabular}

Abbreviations: DH, double-hit; DP, double-positive.

S3F-S3G). Patients with $\mathrm{MYC}^{+} / \mathrm{BCL}^{+}$DLBCL but not $\mathrm{MYC}^{+} / \mathrm{BCL6}^{+}$DLBCL had poorer survival (Figure $5 \mathrm{G}$, Supplementary Figure S3G). The poor prognosis of patients with $\mathrm{MYC}^{+} / \mathrm{BCL}^{+}$DLBCL was attributable to the poorer survival of $\mathrm{MYC}^{+} / \mathrm{BCL} 2^{+}$DLBCL patients.

We further evaluated the survival of patients with isolated $\mathrm{MYC}^{+} / \mathrm{BCL}^{+} / \mathrm{BCL}^{-}$(i.e., BCL6- DPL) versus isolated $\mathrm{MYC}^{+} / \mathrm{BCL}^{+} / \mathrm{BCL}^{-}$(i.e., BCL2- DPL) DLBCL. Patients with isolated $\mathrm{MYC}^{+} / \mathrm{BCL}^{+}$DLBCL had favorable survival compared with isolated $\mathrm{MYC}^{+} / \mathrm{BCL}^{+}$DLBCL patients (OS: $P=0.004$, Figure 5H; PFS: $P<0.0001$, Supplementary Figure $\mathrm{S} 3 \mathrm{H}$ ).

\section{Gene expression signatures of concurrent $M Y C$, $B C L 2$, and $B C L 6$ rearrangements and isolated $\mathrm{MYC}^{+} \mathrm{BCL2}^{+}$and $\mathrm{MYC}^{+} \mathrm{BCL6}^{+}$coexpression}

To better understand the molecular mechanisms of the effects on prognosis, we compared the GEP of patients with concurrent $M Y C / B C L 2$ or $M Y C / B C L 6$ rearrangements with the remaining patients. Only $M Y C / B C L 2$ rearranged DLBCL showed a distinctive GEP signature, whereas concurrent MYC/BCL6 rearranged DLBCL did not show DEGs compared with $M Y C$ rearranged DLBCL or the remaining DLBCL patients. The GEP signature of concurrent $M Y C / B C L 2$ rearranged DLBCL included 24 upregulated genes and 14 downregulated genes at the false discovery rate threshold of 0.01 (Table. 3A, Figure $5 \mathrm{~A}$ ). These genes were involved in signaling (upregulation of $B M P 3, S W A P 70$, and CELSR1, and downregulation of $P L A 2 G 7$ and DOCK10), cell proliferation (upregulated $S T R B P$ and MUC4), metabolism (eight upregulated genes), apoptosis (TMEM49, CFLAR, CARD16 and
$C A S P 1)$, transcription factors and genes related to cell adhesion, extracellular matrix, and migration $(M Y O 3 B$, SLAMF7, SILEC10/12, TPM4, and SRGN).

Comparison of the GEP of $\mathrm{MYC}^{+} \mathrm{BCL}^{+}$versus $\mathrm{MYC}^{+} \mathrm{BCL} 2^{+}$DLBCL did not show significant DEGs. We further compared the GEP of isolated $\mathrm{MYC}^{+} \mathrm{BCL} 2$ $\mathrm{BCL6}^{+}$DLBCL versus isolated $\mathrm{MYC}^{+} \mathrm{BCL}^{+}{ }^{+} \mathrm{BCL} 6-$ DLBCL, which resulted in 36 DEGs at the false discovery rate threshold of 0.05 (Table 3B, Figure 6B). Upregulated genes in $\mathrm{MYC}^{+} \mathrm{BCL} 2 \mathrm{BCL}^{+}$compared with $\mathrm{MYC}^{+} \mathrm{BCL} 2^{+} \mathrm{BCL} 6^{-}$included $B C L 6$, a proliferation signature (MYBL1, NEK6, BRWD1 [bromodomain and WD repeat domain containing 1], SFRS15, HMGN1, and TMPO), MSH6 involved in DNA repair, DNAJC10 which promotes apoptotic in response to endoplasmic reticulum stress, various signaling genes including PIK3CG (PI3K catalytic subunit gamma), STAP1 (B-cell receptor signaling) SORL1, RFTN1, GNA13, SWAP70, and $A N K R D 13 A$, and genes involved in actin cytoskeleton regulation and migration (MARCKSL1, VNN2, OSBPL3, $A C T R 2$ and etc.). Comparably, upregulated genes in $\mathrm{MYC}^{+} \mathrm{BCL2}{ }^{+} \mathrm{BCL}^{-}$included signatures of apoptosis (antiapoptotic $B C L 2$, and paradoxically proapoptotic, CASP10), glutamine metabolism ( $A L D H 4 A 1)$, indicating that abnormal dysregulation of apoptotic and proliferation pathways are critical in patients with $\mathrm{MYC}^{+} \mathrm{BCL} 6^{+} \mathrm{BCL2} 2^{-}$. In contrast, such signaling and molecular defects were not seen in patients with $\mathrm{MYC}^{+} \mathrm{BCL} 6^{-} \mathrm{BCL} 2^{+}$. The observations provide molecular basis for the difference of outcome and survival between these two groups of DLBCL patients. 


\section{DISCUSSION}

In the literature B-cell lymphomas with concurrent $M Y C / B C L 2$ or $M Y C / B C L 6$ rearrangements are grouped together as double-hit B-cell lymphomas [1, 2]. Patients with $M Y C / B C L 2$ DHL have responded poorly to all traditional chemotherapy regimens and have extremely poor outcomes $[1,10,11]$. However, most of what we
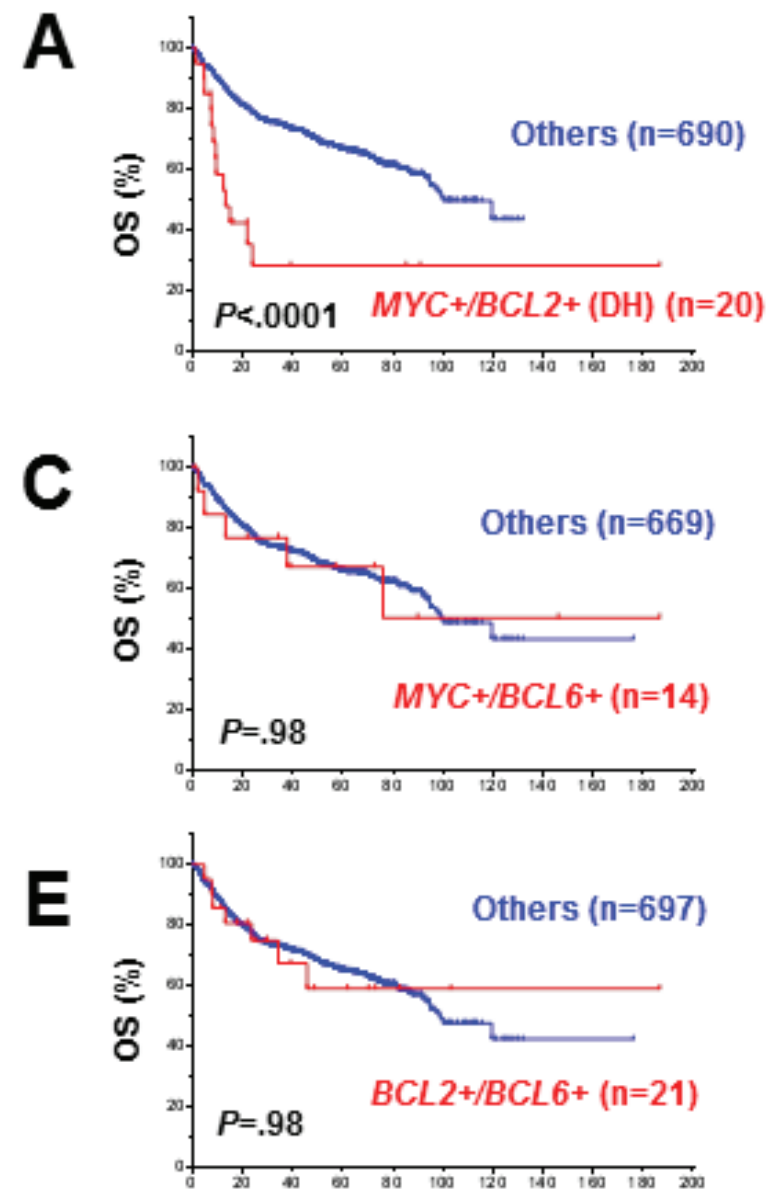

G

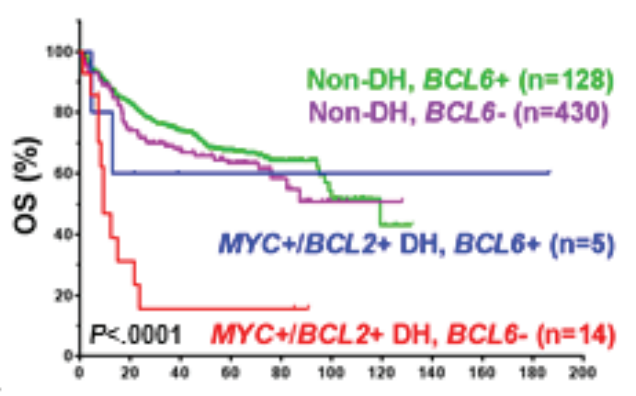

Months know about double-hit B-cell lymphoma is derived from studies of the most common form, MYC/BCL2 DHL. In contrast, very little has been published on DLBCL patients with concurrent $M Y C / B C L 6$ rearrangements. The findings in this study for a group of DLBCL patients treated with R-CHOP suggest that patients with concurrent $M Y C / B C L 6$ rearrangements do not have a poorer prognosis and that grouping these tumors with other forms of DHL could lead to inappropriate therapy.
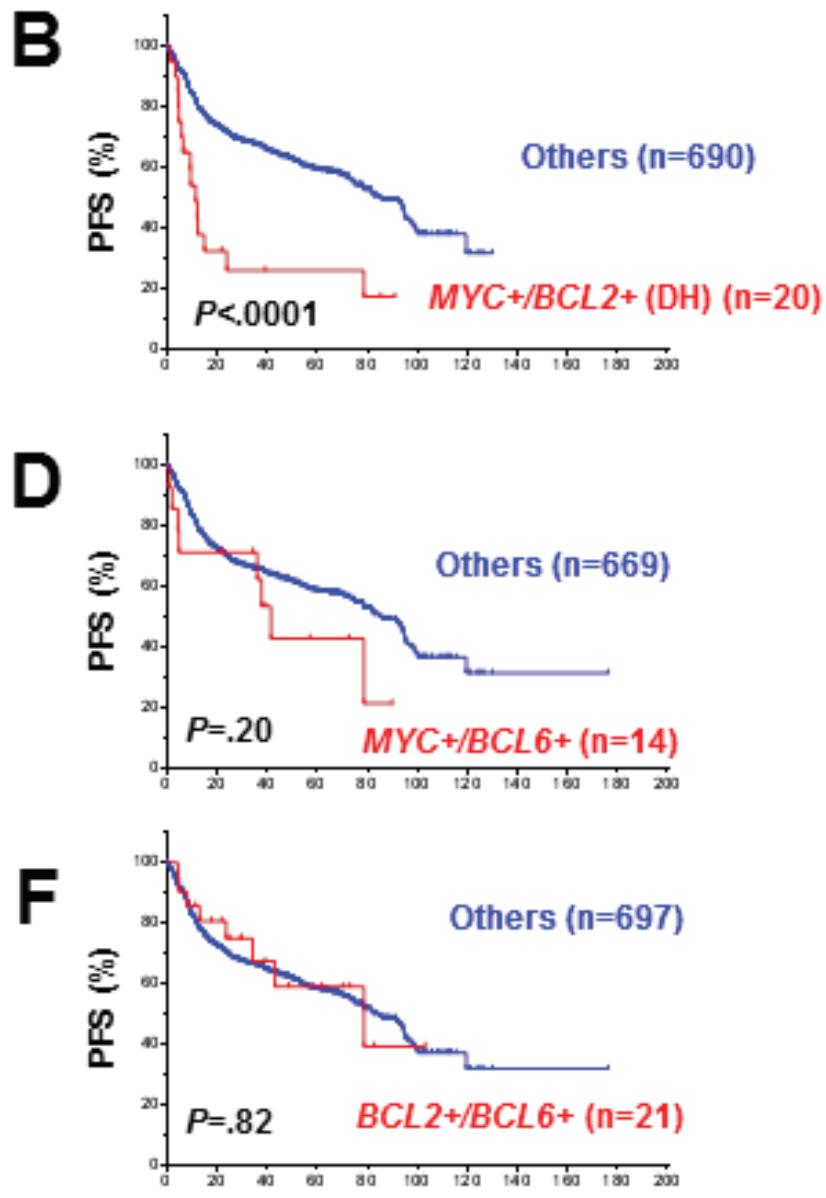

H

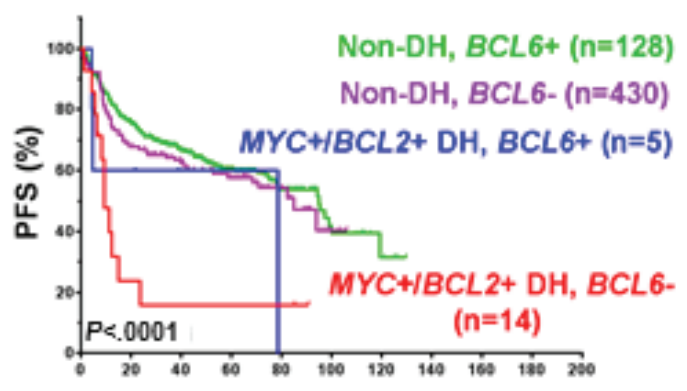

Months

Figure 3: A.-B. Concurrent $M Y C / B C L 2$ rearrangements correlated with significant poorer overall survival. C.-D. Concurrent $M Y C+/$ $B C L 6+$ rearrangements did not correlate with poorer overall survival. E.-F. Concurrent $B C L 2+/ B C L 6+$ rearrangements did not correlate with poorer overall survival. G.-H. BCL6 attenuated the adverse prognostic impact of $M Y C+/ B C L 2+$ double-hit lymphoma. 
In this large cohort of 898 cases of de novo DLBCL, rearrangements of $M Y C, B C L 2$, and $B C L 6$ were found in $11.8 \%, 13.6 \%$ and $23.1 \%$ of cases, respectively. BCL6 rearrangements were more frequently observed in the ABC subtype whereas $M Y C$ and BCL2 rearrangements were more frequently observed in the GCB subtype. Concurrent MYC/BCL6 and MYC/BCL2 rearrangements were observed in $2.0 \%$ and $2.8 \%$ of DLBCL cases, respectively. $M Y C / B C L 2 / B C L 6$ triple-hit was observed in $38 \%$ of $M Y C / B C L 6$ and $26 \%$ of $M Y C / B C L 2$ doublehit cases. The frequencies of $M Y C, B C L 2$, and BCL6 rearrangement and concurrent $M Y C / B C L 2$ rearrangements are similar to those reported in DLBCL in earlier studies [10, 11, 31-34].

In this study, DLBCL patients with concurrent $M Y C /$ $B C L 6$ rearrangements did not have a poorer prognosis. The notion that concurrent MYC/BCL6 rearrangements in DLBCL is not an indication of aggressive lymphoma was further substantiated by the lack of a distinctive GEP signature for $M Y C / B C L 6$ rearranged DLBCL although BCL6 was overexpressed in almost all MYC/BCL6 rearranged patients except one case with an IHC of $30 \%$. These phenomena might be explained by a previous finding that up to $43 \%$ of BCL6 translocations involved non- $I G$ loci showing complex gene expression patterns [35], limited case numbers, and $36 \%$ of MYC/BCL6 cases showing low MYC expression levels (Figure 2G-2H). In contrast, $M Y C / B C L 2$ rearranged DLBCL correlated with significantly poorer survival, and was associated with a distinctive GEP signature suggesting increased proliferation, growth and metabolism and decreased apoptosis pathway (our results showed downregulation of both pro- and anti-apoptotic genes).

In the MD Anderson Cancer Center experience with 52 DHL patients tested for BCL6, 24 patients with $B C L 6$ gene abnormality (translocation or amplification, $n=15$ and $n=9$ respectively. Among them, 14 patients had MYC/BCL2/BCL6 triple-hit) showed slightly better survival than other patients with DHL (hazard ratio: 0.59, 95\% confidence interval: $0.21-1.69, P=0.33$ ) [36]. Ueda et al. presented a case report consistent with our results, in which a person having DLBCL with concurrent $M Y C$, $B C L 2$, and BCL6 rearrangements achieved complete remission after chemoradiotherapy for two years [37]. A recent study reported the largest DHL series including 41 cases with BCL6 rearrangement, in which patients' OS was not significantly affected by whether the DHL was $M Y C / B C L 2$ or $M Y C / B C L 6(P=0.537)$. However, $25(58.5 \%)$ of the 41 MYC/BCL6 patients also had BCL2 rearrangement (triple-hit) [38]. In contrast, in another study, MYC/BCL6 $(n=13)$ showed significantly worse survival than $M Y C / B C L 2$ DHL $(n=20)$ after exclusion of triple-hit lymphoma [39]. These MYC/BCL6 DHL showed a trend toward higher $M Y C$ mRNA expression and a distinct gene expression profile compared to $M Y C / B C L 2$ DHL. In a smaller study reported by Pillai et al. B-cell
A

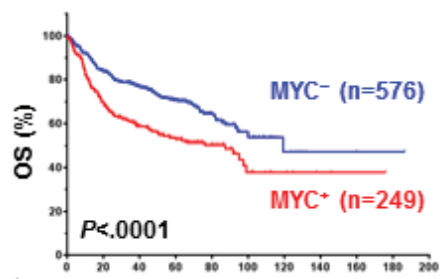

D

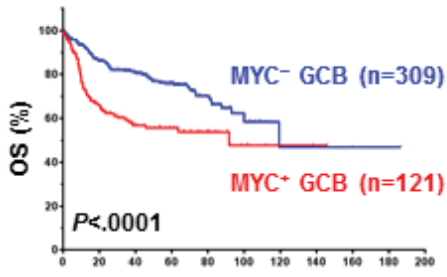

G

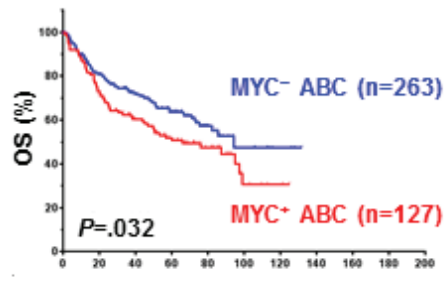

Months
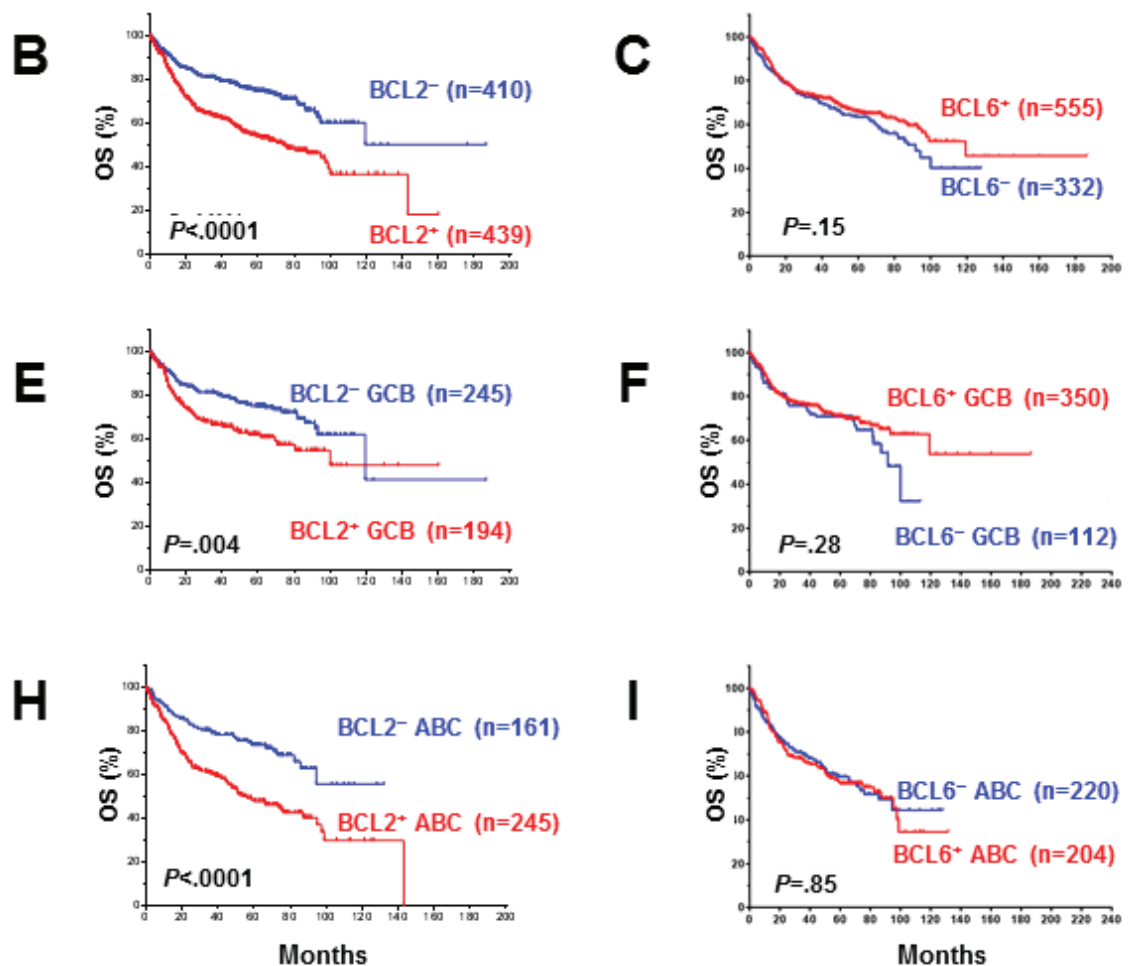

Figure 4: Univariate analysis for DLBCL patients with MYC, BCL2 and BCL6 protein expression in the overall-, GCB, and ABC-DLBCL. A.-B., D.-E., G.-H. MYC and BCL2 protein expression correlated with significantly poorer overall survival in overall, GCB- and ABC-DLBCL. C., F., I. BCL6 overexpression did not correlate with poor survival. 
lymphoma with concurrent $M Y C / B C L 6$ rearrangements was associated with aggressive clinical course and poor survival [40]. A possible explanation for the discrepancy is patient selection. In the study by Pillai et al, patients with BL, BL-like lymphoma, and primary effusion lymphoma were also included. Moreover, the median age of their patients was 83 years and only one of six patients with adequate information received chemotherapy in
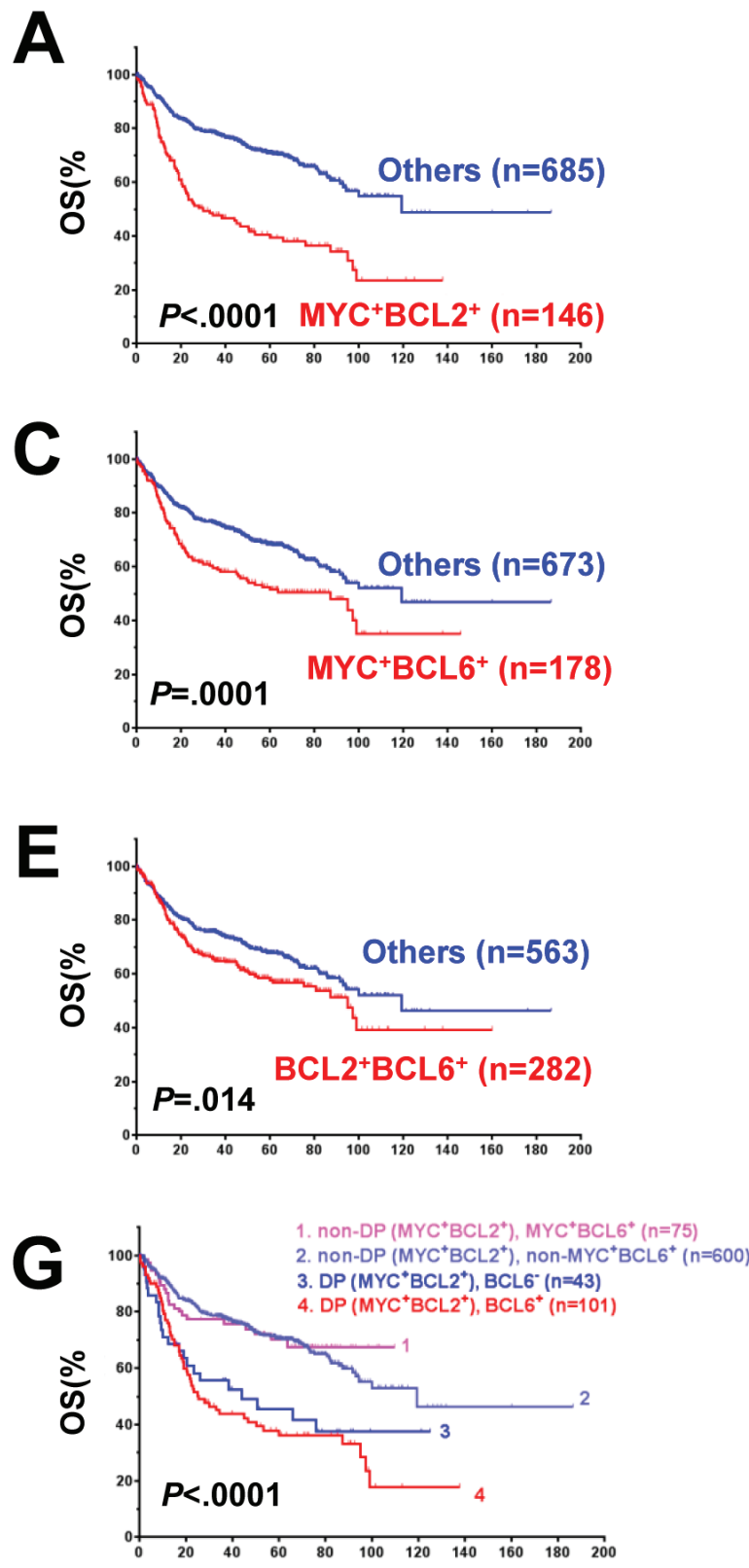

Months combination with rituximab [40]. In this study, all patients met morphologic and immunophenotypic criteria for DLBCL with a median patient age of 64 years, which is comparable to that of patients with DLBCL without concurrent MYC/BCL6 rearrangements, and all patients were treated with standard R-CHOP therapy.

Recently, the concept of $M Y C / B C L 2$ rearranged DHL has been extended to MYC and BCL2 protein

B

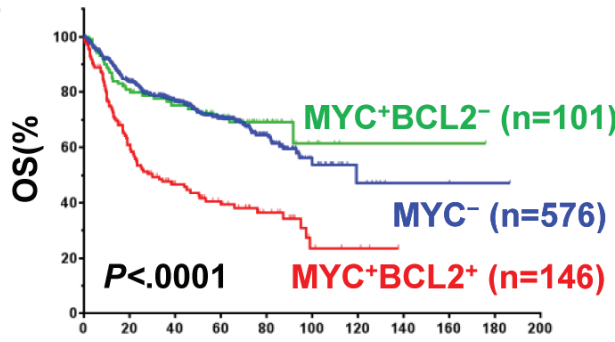

D

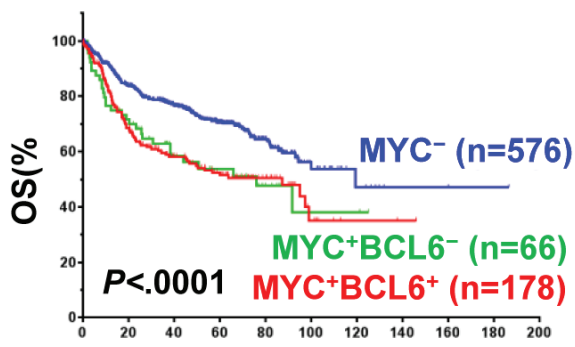

$\mathbf{F}$
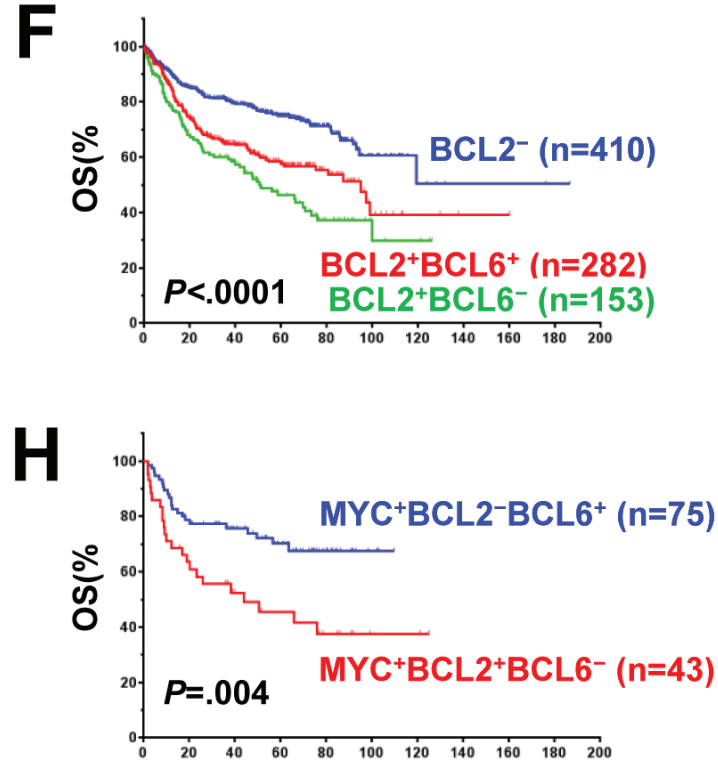

Months

Figure 5: A., C., E. Patients with DLBCL and MYC/BCL2, BCL6/MYC or BCL2/BCL6 co-expression had significantly poorer overall survival in the DBLCL cohort. B. BCL2 overexpression had a synergetic effect with MYC overexpression and the adverse prognostic impact of MYC depended on BCL2 overexpression. D. BCL6 expression had no synergetic effect with MYC expression. F. BCL6 expression appeared to attenuate the adverse prognostic impact of BCL2 overexpression. $\mathbf{G}$. The poorer overall survival of $\mathrm{MYC}^{+} \mathrm{BCL} 6^{+}$patients was due to the poor survival of $\mathrm{MYC}^{+} \mathrm{BCL} 2^{+}$patients. H. Isolated $\mathrm{MYC}^{+} \mathrm{BCL}^{+}$versus $\mathrm{MYC}^{+} \mathrm{BCL} 2^{+}$double-positive DLBCL had significantly better patient survival. 
coexpression $[11,22,23]$. These studies showed that patients with DLBCL with MYC/BCL2 double-positive (by immunohistochemistry) also have a dismal prognosis, regardless of the status of $M Y C$ or BCL2 rearrangement
$[11,22,23]$. In this study, DLBCL patients with MYC/ BCL6 coexpression showed a significantly poorer survival than DLBCL patients without MYC/BCL6 coexpression. However, this prognostic effect was significant only in

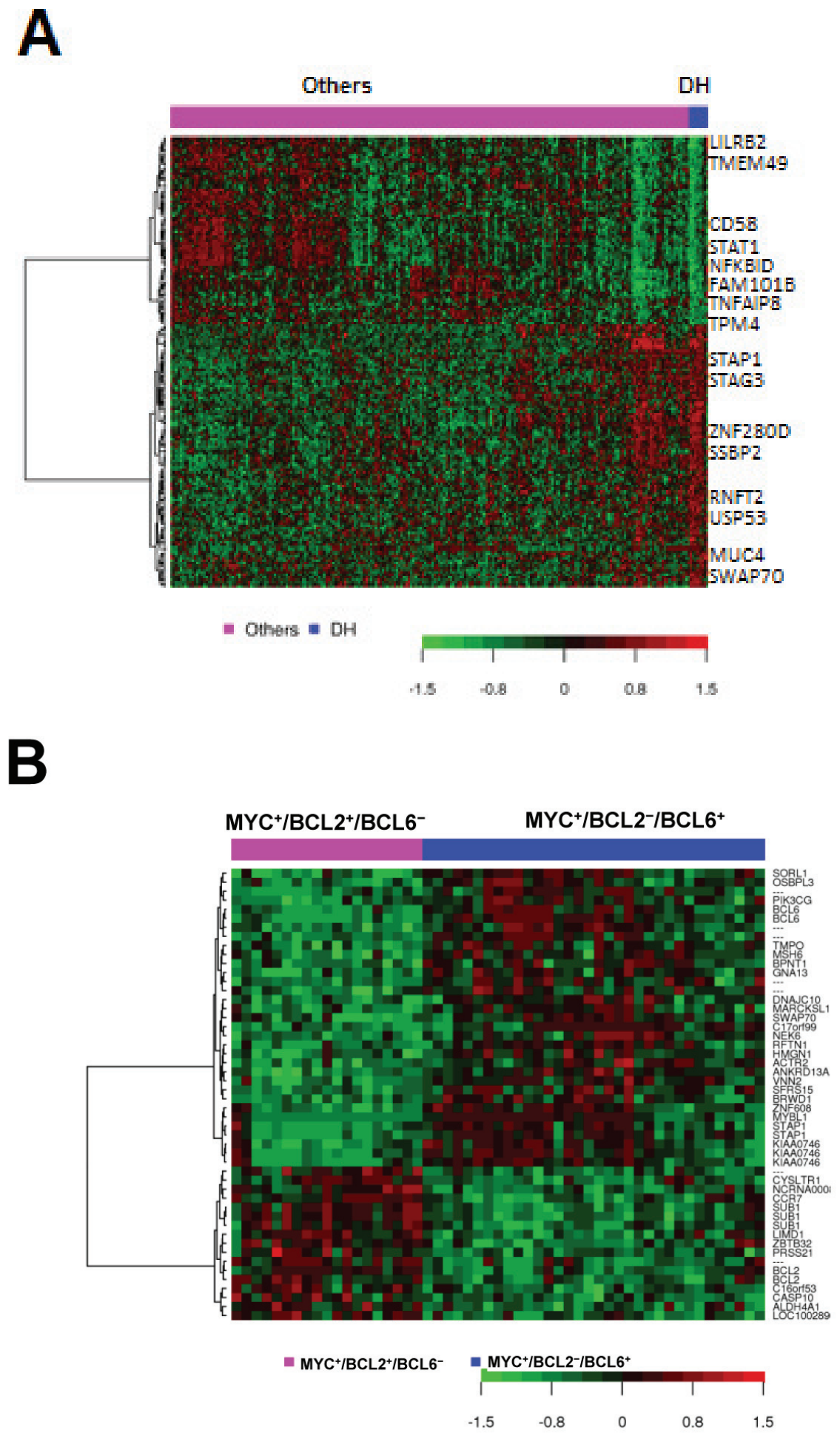

Figure 6: Gene expression signature for $M Y C / B C L 2$ double-hit DLBCL (A) and comparison of $\mathrm{MYC}^{+} \mathrm{BCL2}^{+} \mathrm{BCL6}^{-}$ versus $\mathrm{MYC}^{+} \mathrm{BCL2}^{-} \mathrm{BCL6}^{+}$translocation in DLBCL (B). 
the presence of DLBCL with MYC/BCL2 coexpression.

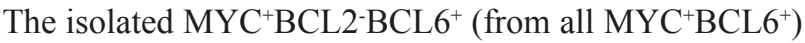
subgroup had significantly better patient survival compared with the $\mathrm{MYC}^{+} \mathrm{BCL}^{+} \mathrm{BCL}^{-}$(from all $\mathrm{MYC}^{+} \mathrm{BCL}^{+}$) subgroup. Previous studies also suggested that BCL6 expression is associated with favorable survival in patients with DLBCL [24, 30, 41, 42].

There is a biologic basis that may explain the lack of significantly adverse prognostic impact of recurrent $M Y C$ / BCL6 rearrangements and MYC/BCL6 coexpression. BCL6 represses CCND2 and MYC [27-29, 43]; we have recently shown that MYC expression levels significantly impact the prognosis of $M Y C$ rearranged DLBCL [44], and our multivariate analysis suggested BCL6 expression correlated with favorable survival $(P=0.048$ for OS and $P=0.016$ for PFS, Table 1$)$, therefore the adverse prognostic impact of MYC might have been diminished by high BCL6 expression in these cases. In addition to the potential role of BCL6, the GEP signature of $\mathrm{MYC}^{+} \mathrm{BCL} 2$ $\mathrm{BCL}^{+}$DLBCL suggested DNA repair and proapoptosis, in contrast with the upregulation of antiapoptotic $B C L 2$ in $\mathrm{MYC}^{+} \mathrm{BCL}^{+} \mathrm{BCL}^{-}$DLBCL. Interestingly, MYBL1 and LIMD1 were also significantly upregulated in our $\mathrm{MYC}^{+} \mathrm{BCL2} \mathrm{BCL6}^{+}$(associated with GCB) and $\mathrm{MYC}^{+} \mathrm{BCL}^{+}{ }^{+} \mathrm{BCL}^{-}$(associated with $\mathrm{ABC}$ ) DLBCL subgroup respectively, which is in consistent with the correlations between a novel two-gene expression index, "LIMD1-MYBL1 Index", and GCB/ABC subtypes and clinical outcome $[45,46]$.

In summary, DLBCL patients with concurrent $M Y C /$ $B C L 6$ rearrangements are not necessarily associated with an inferior prognosis when treated with R-CHOP therapy, unlike DLBCL patients with concurrent $M Y C / B C L 2$ rearrangements, probably due to different pathogenesis and MYC expression levels. In addition, DLBCL patients with MYC/BCL6 coexpression did have an inferior prognosis, but only in the presence of MYC/BCL2 coexpression, and therefore $\mathrm{MYC}$ /BCL6 coexpression seems to be of less prognostic importance [46]. These data support the notion that DLBCL with concurrent $M Y C /$ $B C L 6$ rearrangements and DLBCL with $M Y C / B C L 2$ DHL are not equivalent prognostically. These results suggest that the concept of double-hit lymphoma needs to be refined. The grouping of cases of DLBCL with concurrent $M Y C / B C L 6$ rearrangements with cases of DLBCL with $M Y C / B C L 2$ rearrangements may lead to over treatment of $M Y C / B C L 6$ rearranged DLBCL patients.

\section{PATIENTS, MATERIALS AND METHODS}

\section{Patients}

A cohort of 898 patients with de novo DLBCL treated with standard rituximab, cyclophosphamide, doxorubicin, vincristine and prednisolone (R-CHOP) therapy was collected as part of The International DLBCL Rituximab-CHOP Consortium Program Study [33,46]. All patients were diagnosed according to the World Health Organization (WHO) classification system and received treatment between 1998 and 2010. Cases were excluded if patients had a history of low-grade B-cell lymphoma; human immunodeficiency virus infection; or primary mediastinal, cutaneous B cell lymphoma, or central nervous system DLBCL. This study was approved by the Institutional Review Boards of each participating center, and the comprehensive collaborative study was approved by the Institutional Review Board at The University of Texas MD Anderson Cancer Center.

\section{Tissue microarray, immunohistochemistry and fluorescence in situ hybridization}

Construction of tissue microarrays, IHC staining procedures on tissue microarray sections, and scoring criteria for MYC, BCL2 and BCL6 have been described previously [23, 44, 47]. MYC (clone Y69; Epitomics, Burlingame, CA) and BCL6 (clone LN22; Leica Microsystems, Buffalo Grove, IL) expression showed a distinct nuclear pattern and BCL2 (clone 124; DAKO, Denmark) expression exhibited a cytoplasmic pattern. Cutoffs for MYC, BCL2 and BCL6 overexpression are determined as $\geq 70 \%, \geq 70 \%$, and $>50 \%$ respectively based on survival analysis as described previously, and cutoffs and positivity rates reported by other study groups.

Interphase fluorescence in situ hybridization (FISH) analysis was performed using formalin-fixed, paraffinembedded tissue sections and BCL2 and BCL6 dual-color, break-apart probes (Vysis), IGH/MYC/CEP8 tricolor dualfusion probes (Vysis) and a locus specific MYC dual-color break-apart probe (Vysis) as described previously [47].

\section{Gene expression profiling and COO classification}

Gene expression profiling (GEP) was performed on formalin-fixed, paraffin-embedded tissue samples using Affymetrix GeneChip HG-U133 Plus Version 2.0 (Affymetrix, Santa Clara, CA) as described in an earlier study [47]. The CEL files are deposited in the National Center for Biotechnology Information Gene Expression Omnibus repository (GSE\#31312). ${ }^{61}$ The microarray data were quantified and normalized by the frozen robust multiarray analysis (RMA) algorithm [48]. Differential expression gene (DEG) analysis was performed using multiple $t$-tests [31, 47]. Cell-of-origin classification into either GCB or ABC subtypes was achieved by using either GEP $(n=497)$ or IHC methods $(n=401)$ according to the Visco-Young (first selection) and Choi (the second selection) algorithms [49-53]. 


\section{Statistical analysis}

Clinical and laboratory features of DLBCL patients at the time of presentation according to different subgroups were compared using the chi-squared test and the Spearman rank correlation test. Overall survival (OS) was calculated from the date of diagnosis to the date of last follow-up or death. Progression-free survival (PFS) was calculated from the date of diagnosis to the time of progression or death. Kaplan-Meier survival curves were used to estimate OS and PFS rates, and the logrank (Mantel-Cox) test was used to assess differences in survival between groups. Multivariate analysis for survival was performed with IBM statistics SPSS 19 software using the Cox proportional hazards regression model (Chicago, SPSS Inc.). All differences with $P \leq 0.05$ were considered to be statistically significant.

\section{ACKNOWLEDGMENTS}

This study is supported by the National Cancer Institute and National Institutes of Health grants (R01CA138688 and R01CA187415, K.H.Y). QY is the recipient of pathology scholarship award from Jiangsu Province for Oversea Studies (JS-2011-093) and Nanjing Medical Science and Technology Development Foundation (ORX11080).. ZYXM is the recipient of the Harold C. and Mary L. Daily Endowment Fellowships and Shannon Timmins Fellowship for Leukemia Research Award. KHY is supported by The University of Texas MD Anderson Cancer Center Lymphoma Moonshot Program, Institutional Research Grant Award, an MD Anderson Lymphoma Specialized Programs of Research Excellence (SPORE) Research Development Program Award, an MD Anderson Myeloma SPORE Research Development Program Award, MD Anderson Collaborative Research Funds with High-Throughput Molecular Diagnostics, Gilead Pharmaceutical, Adaptive Biotechnology, Seattle Genetics, and Roche Molecular Systems. This work was also partially supported by National Cancer Institute and National Institutes of Health grants (P50CA136411 and P50CA142509), and by the MD Anderson Cancer Center Support Grant CA016672.

\section{Authors' Contributions}

Conception and design: SH, ZYXM, KHY; Research performance: QY, ZYXM, AT, KHY; Provision of study materials, key reagents and technology: QY, ZYXM, LD, AT, XW, GCM, CV, LZ, SMM, , KD, AC, AO, YZ, GB, KLR, EDH, WWLC, JHK, JH, MP, AJMF, BMP, MBM, MAP, JNW, S.H., LJM, KHY; Collection and assembly of data under approved IRB and MTA: ZYXM, AT, CV, SMM, , KD, AC, AO, YZ, GB, KLR, EDH, WWLC, JHK, JH, MP, AJMF, BMP, MBM, MAP, JNW, KHY; Data analysis and interpretation: QY, ZYXM, LD, XW, SH, KHY; Manuscript writing: YQ, ZYXM, LD, XW, LJM, SH, KHY; Final approval of manuscript: All authors.

\section{CONFLICTS OF INTEREST}

The authors declare no conflicts of interest.

\section{EDITORIAL NOTE}

This paper has been accepted based in part on peerreview conducted by another journal and the authors' response and revisions as well as expedited peer-review in Oncotarget.

\section{REFERENCES}

1. Aukema SM, Siebert R, Schuuring E, van Imhoff GW, Kluin-Nelemans HC, Boerma EJ, Kluin PM. Double-hit B-cell lymphomas. Blood. 2011; 117:2319-31.

2. Sinha P, Hutter G, Kottgen E, Dietel M, Schadendorf D, Lage H. Increased expression of epidermal fatty acid binding protein, cofilin, and 14-3-3-sigma (stratifin) detected by two-dimensional gel electrophoresis, mass spectrometry and microsequencing of drug-resistant human adenocarcinoma of the pancreas. Electrophoresis. 1999; 20:2952-60.

3. Barrans S, Crouch S, Smith A, Turner K, Owen R, Patmore $\mathrm{R}$, Roman E, Jack A. Rearrangement of MYC is associated with poor prognosis in patients with diffuse large B-cell lymphoma treated in the era of rituximab. J Clin Oncol. 2010; 28:3360-5.

4. Savage KJ, Johnson NA, Ben-Neriah S, Connors JM, Sehn LH, Farinha P, Horsman DE, Gascoyne RD. MYC gene rearrangements are associated with a poor prognosis in diffuse large B-cell lymphoma patients treated with R-CHOP chemotherapy. Blood. 2009; 114:3533-7.

5. Klapper W, Stoecklein H, Zeynalova S, Ott G, Kosari F, Rosenwald A, Loeffler M, Trumper L, Pfreundschuh M, Siebert R, German High-Grade Non-Hodgkin's Lymphoma Study G. Structural aberrations affecting the MYC locus indicate a poor prognosis independent of clinical risk factors in diffuse large B-cell lymphomas treated within randomized trials of the German High-Grade Non-Hodgkin's Lymphoma Study Group (DSHNHL). Leukemia.2008; 22:2226-9.

6. Ott G, Rosenwald A, Campo E. Understanding MYCdriven aggressive B-cell lymphomas: pathogenesis and classification. Blood. 2013; 122:3884-91.

7. Valera A, Lopez-Guillermo A, Cardesa-Salzmann T, Climent F, Gonzalez-Barca E, Mercadal S, Espinosa I, Novelli S, Briones J, Mate JL, Salamero O, Sancho JM, Arenillas L, et al. MYC protein expression and genetic alterations have prognostic impact in patients with diffuse large B-cell lymphoma treated with immunochemotherapy. 
Haematologica. 2013; 98:1554-62.

8. Cheah CY, Oki Y, Westin JR, Turturro F. A clinician's guide to double-hit lymphomas. Br J Haematol. 2015; 168:784-95

9. Petrich AM, Nabhan C, Smith SM. MYC-associated and double-hit lymphomas: a review of pathobiology, prognosis, and therapeutic approaches. Cancer. 2014; 120:3884-95.

10. Friedberg JW. Double-hit diffuse large B-cell lymphoma. J Clin Oncol. 2012; 30:3439-43.

11. Johnson NA, Slack GW, Savage KJ, Connors JM, BenNeriah S, Rogic S, Scott DW, Tan KL, Steidl C, Sehn LH, Chan WC, Iqbal J, Meyer PN, et al. Concurrent expression of MYC and BCL2 in diffuse large B-cell lymphoma treated with rituximab plus cyclophosphamide, doxorubicin, vincristine, and prednisone. J Clin Oncol. 2012; 30:3452-9.

12. Patel JH, McMahon SB. BCL2 is a downstream effector of MIZ-1 essential for blocking c-MYC-induced apoptosis. J Biol Chem. 2007; 282:5-13.

13. Johnson NA, Savage KJ, Ludkovski O, Ben-Neriah S, Woods R, Steidl C, Dyer MJ, Siebert R, Kuruvilla J, Klasa R, Connors JM, Gascoyne RD, Horsman DE. Lymphomas with concurrent BCL2 and MYC translocations: the critical factors associated with survival. Blood. 2009; 114:2273-9.

14. Kanungo A, Medeiros LJ, Abruzzo LV, Lin P. Lymphoid neoplasms associated with concurrent $t(14 ; 18)$ and 8q24/cMYC translocation generally have a poor prognosis. Mod Pathol. 2006; 19:25-33.

15. Le Gouill S, Talmant P, Touzeau C, Moreau A, Garand R, Juge-Morineau N, Gaillard F, Gastinne T, Milpied N, Moreau P, Harousseau JL, Avet-Loiseau H. The clinical presentation and prognosis of diffuse large B-cell lymphoma with $\mathrm{t}(14 ; 18)$ and $8 \mathrm{q} 24 / \mathrm{c}-\mathrm{MYC}$ rearrangement. Haematologica. 2007; 92:1335-42.

16. Li S, Lin P, Fayad LE, Lennon PA, Miranda RN, Yin CC, Lin E, Medeiros LJ. B-cell lymphomas with MYC/8q24 rearrangements and IGH@BCL2/t(14;18)(q32;q21): an aggressive disease with heterogeneous histology, germinal center B-cell immunophenotype and poor outcome. Mod Pathol. 2012; 25:145-56.

17. Lin P, Medeiros LJ. High-grade B-cell lymphoma/leukemia associated with $\mathrm{t}(14 ; 18)$ and 8q24/MYC rearrangement: a neoplasm of germinal center immunophenotype with poor prognosis. Haematologica. 2007; 92:1297-301.

18. Niitsu N, Okamoto M, Miura I, Hirano M. Clinical features and prognosis of de novo diffuse large B-cell lymphoma with $\mathrm{t}(14 ; 18)$ and $8 \mathrm{q} 24 / \mathrm{c}-\mathrm{MYC}$ translocations. Leukemia. 2009; 23:777-83.

19. Snuderl M, Kolman OK, Chen YB, Hsu JJ, Ackerman AM, Dal Cin P, Ferry JA, Harris NL, Hasserjian RP, Zukerberg LR, Abramson JS, Hochberg EP, Lee H, et al. B-cell lymphomas with concurrent IGH-BCL2 and MYC rearrangements are aggressive neoplasms with clinical and pathologic features distinct from Burkitt lymphoma and diffuse large B-cell lymphoma. Am J Surg Pathol. 2010;
$34: 327-40$

20. Tomita N, Tokunaka M, Nakamura N, Takeuchi K, Koike J, Motomura S, Miyamoto K, Kikuchi A, Hyo R, Yakushijin Y, Masaki Y, Fujii S, Hayashi T, et al. Clinicopathological features of lymphoma/leukemia patients carrying both BCL2 and MYC translocations. Haematologica. 2009; 94:935-43.

21. Alizadeh AA, Eisen MB, Davis RE, Ma C, Lossos IS, Rosenwald A, Boldrick JC, Sabet H, Tran T, Yu X, Powell JI, Yang L, Marti GE, et al. Distinct types of diffuse large B-cell lymphoma identified by gene expression profiling. Nature. 2000; 403:503-11.

22. Green TM, Young KH, Visco C, Xu-Monette ZY, Orazi A, Go RS, Nielsen O, Gadeberg OV, MouritsAndersen T, Frederiksen M, Pedersen LM, Moller MB. Immunohistochemical double-hit score is a strong predictor of outcome in patients with diffuse large B-cell lymphoma treated with rituximab plus cyclophosphamide, doxorubicin, vincristine, and prednisone. J Clin Oncol. 2012; 30:3460-7.

23. $\mathrm{Hu} \mathrm{S}, \mathrm{Xu}-$ Monette $\mathrm{ZY}$, Tzankov A, Green T, Wu L, Balasubramanyam A, Liu WM, Visco C, Li Y, Miranda RN, Montes-Moreno S, Dybkaer K, Chiu A, et al. MYC/BCL2 protein coexpression contributes to the inferior survival of activated B-cell subtype of diffuse large B-cell lymphoma and demonstrates high-risk gene expression signatures: a report from The International DLBCL Rituximab-CHOP Consortium Program. Blood. 2013; 121:4021-31; quiz 4250.

24. Horn H, Ziepert M, Becher C, Barth TF, Bernd HW, Feller AC, Klapper W, Hummel M, Stein H, Hansmann ML, Schmelter C, Moller P, Cogliatti S, et al. MYC status in concert with BCL2 and BCL6 expression predicts outcome in diffuse large B-cell lymphoma. Blood. 2013; 121:225363.

25. Valera A, Lopez-Guillermo A, Cardesa-Salzmann T, Climent F, Gonzalez-Barca E, Mercadal S, Espinosa I, Novelli S, Briones J, Mate JL, Salamero O, Sancho JM, Arenillas L, et al. MYC protein expression and genetic alterations have prognostic impact in patients with diffuse large B-cell lymphoma treated with immunochemotherapy. Haematologica. 2013; 98:1554-62.

26. Perry AM, Alvarado-Bernal Y, Laurini JA, Smith LM, Slack GW, Tan KL, Sehn LH, Fu K, Aoun P, Greiner TC, Chan WC, Bierman PJ, Bociek RG, et al. MYC and BCL2 protein expression predicts survival in patients with diffuse large B-cell lymphoma treated with rituximab. Br J Haematol. 2014; 165:382-91.

27. Basso K, Dalla-Favera R. BCL6: master regulator of the germinal center reaction and key oncogene in $\mathrm{B}$ cell lymphomagenesis. Adv Immunol. 2010; 105:193-210.

28. Klein U, Tu Y, Stolovitzky GA, Keller JL, Haddad J, Jr., Miljkovic V, Cattoretti G, Califano A, Dalla-Favera R. Transcriptional analysis of the B cell germinal center reaction. Proc Natl Acad Sci U S A. 2003; 100:2639-44. 
29. Shaffer AL, Yu X, He Y, Boldrick J, Chan EP, Staudt LM. BCL-6 represses genes that function in lymphocyte differentiation, inflammation, and cell cycle control. Immunity. 2000; 13:199-212.

30. Iqbal J, Greiner TC, Patel K, Dave BJ, Smith L, Ji J, Wright G, Sanger WG, Pickering DL, Jain S, Horsman DE, Shen Y, Fu K, et al. Distinctive patterns of BCL6 molecular alterations and their functional consequences in different subgroups of diffuse large B-cell lymphoma. Leukemia. 2007; 21:2332-43.

31. Choi WW, Weisenburger DD, Greiner TC, Piris MA, Banham AH, Delabie J, Braziel RM, Geng H, Iqbal J, Lenz G, Vose JM, Hans CP, Fu K, et al. A new immunostain algorithm classifies diffuse large B-cell lymphoma into molecular subtypes with high accuracy. Clin Cancer Res. 2009; 15:5494-502.

32. Tzankov A, Xu-Monette ZY, Gerhard M, Visco C, Dirnhofer S, Gisin N, Dybkaer K, Orazi A, Bhagat G, Richards KL, Hsi ED, Choi WW, van Krieken JH, et al. Rearrangements of MYC gene facilitate risk stratification in diffuse large B-cell lymphoma patients treated with rituximab-CHOP. Mod Pathol. 2014; 27:958-71.

33. Xu-Monette ZY, Wu L, Visco C, Tai YC, Tzankov A, Liu WM, Montes-Moreno S, Dybkaer K, Chiu A, Orazi A, Zu Y, Bhagat G, Richards KL, et al. Mutational profile and prognostic significance of TP53 in diffuse large B-cell lymphoma patients treated with R-CHOP: report from an International DLBCL Rituximab-CHOP Consortium Program Study. Blood. 2012; 120:3986-96.

34. Shustik J, Han G, Farinha P, Johnson NA, Ben Neriah S, Connors JM, Sehn LH, Horsman DE, Gascoyne RD, Steidl C. Correlations between BCL6 rearrangement and outcome in patients with diffuse large B-cell lymphoma treated with CHOP or R-CHOP. Haematologica. 2010; 95:96-101.

35. Akasaka H, Akasaka T, Kurata M, Ueda C, Shimizu A, Uchiyama T, Ohno H. Molecular anatomy of BCL6 translocations revealed by long-distance polymerase chain reaction-based assays. Cancer Res. 2000; 60:2335-41.

36. Oki Y, Noorani M, Lin P, Davis RE, Neelapu SS, Ma L, Ahmed M, Rodriguez MA, Hagemeister FB, Fowler N, Wang M, Fanale MA, Nastoupil L, et al. Double-hit lymphoma: the MD Anderson Cancer Center clinical experience. Br J Haematol. 2014; 166:891-901.

37. Ueda C, Nishikori M, Kitawaki T, Uchiyama T, Ohno H. Coexistent rearrangements of c-MYC, BCL2, and BCL6 genes in a diffuse large B-cell lymphoma. Int J Hematol. 2004; 79:52-4.

38. Petrich AM, Gandhi M, Jovanovic B, Castillo JJ, Rajguru S, Yang DT, Shah KA, Whyman JD, Lansigan F, HernandezIlizaliturri FJ, Lee LX, Barta SK, Melinamani S, et al. Impact of induction regimen and stem cell transplantation on outcomes in double-hit lymphoma: a multicenter retrospective analysis. Blood. 2014; 124:2354-61.
39. Aukema SM, Kreuz M, Kohler CW, Rosolowski M, Hasenclever D, Hummel M, Kuppers R, Lenze D, Ott G, Pott C, Richter J, Rosenwald A, Szczepanowski M, et al. Biological characterization of adult MYC-translocationpositive mature B-cell lymphomas other than molecular Burkitt lymphoma. Haematologica. 2014; 99:726-35.

40. Pillai RK, Sathanoori M, Van Oss SB, Swerdlow SH. Double-hit B-cell lymphomas with BCL6 and MYC translocations are aggressive, frequently extranodal lymphomas distinct from BCL2 double-hit B-cell lymphomas. Am J Surg Pathol. 2013; 37:323-32.

41. Lossos IS, Czerwinski DK, Alizadeh AA, Wechser MA, Tibshirani R, Botstein D, Levy R. Prediction of survival in diffuse large-B-cell lymphoma based on the expression of six genes. N.Engl.J.Med. 2004; 350:1828-1837.

42. Lossos IS, Jones CD, Warnke R, Natkunam Y, Kaizer H, Zehnder JL, Tibshirani R, Levy R. Expression of a single gene, BCL-6, strongly predicts survival in patients with diffuse large B-cell lymphoma. Blood. 2001; 98:945-51.

43. Nahar R, Ramezani-Rad P, Mossner M, Duy C, Cerchietti L, Geng H, Dovat S, Jumaa H, Ye BH, Melnick A, Muschen M. Pre-B cell receptor-mediated activation of BCL6 induces pre-B cell quiescence through transcriptional repression of MYC. Blood. 2011; 118:4174-8.

44. Xu-Monette ZY, Dabaja BS, Wang X, Tu M, Manyam GC, Tzankov A, Xia Y, Zhang L, Visco C, Dybkaer K, Chiu A, Orazi A, Zu Y, et al. Clinical features, tumor biology and prognosis associated with MYC rearrangement and overexpression in diffuse large B-cell lymphoma patients treated with rituximab-CHOP. Mod Pathol. 2015. [Epub ahead of print].

45. Xu Q, Tan C, Ni S, Wang Q, Wu F, Liu F, Ye X, Meng X, Sheng W, Du X. Identification and validation of a two-gene expression index for subtype classification and prognosis in Diffuse Large B-Cell Lymphoma. Sci Rep. 2015; 5:10006.

46. Cai Q, Medeiros LJ, Xu X, Young KH. MYC-driven aggressive B-cell lymphomas: Biology, Entity, Differential Diagnosis and Clinical Management. Oncotarget. 2015; 6:38591-616. doi: 10.18632/oncotarget.5774.

47. Visco C, Li Y, Xu-Monette ZY, Miranda RN, Green TM, Li Y, Tzankov A, Wen W, Liu WM, Kahl BS, d'Amore ES, Montes-Moreno S, Dybkaer K, et al. Comprehensive gene expression profiling and immunohistochemical studies support application of immunophenotypic algorithm for molecular subtype classification in diffuse large B-cell lymphoma: a report from the International DLBCL Rituximab-CHOP Consortium Program Study. Leukemia. 2012; 26:2103-13.

48. McCall MN, Bolstad BM, Irizarry RA. Frozen tissue multiarray analysis (fRMA). Biostatistics. 2010: 11:242-53.

49. Chen J, Xu-Monette ZY, Deng L, Shen Q, Manyam GC, Martinez-Lopez A, Zhang L, Montes-Moreno S, Visco C, Tzankov A, Yin L, Dybkaer K, Chiu A, et al. 
Dysregulated CXCR4 expression promotes lymphoma cell survival and independently predicts disease progression in germinal center B-cell-like diffuse large B-cell lymphoma. Oncotarget. 2015; 6:5597-614. doi: 10.18632/ oncotarget. 3343.

50. Li L, Xu-Monette ZY, Manyam GC, Montes-Moreno S, Tzankov A, Visco C, Dybkær K, Routbort MJ, Zhang L, Chiu A, Orazi A, Zu Y, Bhagat G, et al. Prognostic Impact of c-Rel Nuclear Expression and REL amplification and Crosstalk between c-Rel and the p53 Pathway in Diffuse Large B-Cell. Oncotarget. 2015; 6:23157-80. doi: 10.18632/ oncotarget. 4319 .

51. Liu Z, Xu-Monette ZY, Cao X, Manyam GC, Wang X, Tzankov A, Xia Y, Li X, Visco C, Sun R, Zhang L, MontesMoreno S, Dybkær K, et al. Prognostic and biological significance of survivin expression in patients with diffuse large B-cell lymphoma treated with rituximab-CHOP therapy. Mod Pathol. August 7 [Epub ahead of print].

52. Ok CY, Xu-Monette ZY, Li L, Manyam GC, MontesMoreno S, Tzankov A, Visco C, Dybkær K, Routbort MJ, Zhang L, Chiu A, Orazi A, Zu Y, et al. Evaluation of NF$\kappa \mathrm{B}$ subunit expression and signaling pathway activation demonstrates that $\mathrm{p} 52$ expression confers better outcome in germinal center B-cell-like diffuse large B-cell lymphoma in association with CD30 and BCL2 functions. Mod Pathol .2015; 28:1202-13

53. Ok CY, Chen J, Xu-Monette ZY, Tzankov A, Manyam GC, Li L, Visco C, Montes-Moreno S, Dybkær K, Chiu A, Orazi A, Zu Y, Bhagat G, et al. Clinical Implications of Phosphorylated STAT3 Expression in De Novo Diffuse Large B-cell Lymphoma. Clin Cancer Res. 2015; 20:511323. 